Original paper

\title{
Comparison of lithology and tectonometamorphic evolution of units at the northern margin of the Moldanubian Zone: implications for geodynamic evolution in the northeastern part of the Bohemian Massif
}

\author{
Jaroslava PERTOLDOVÁ ${ }^{1 *}$, Kryštof VERNER ${ }^{1,2}$, Stanislav VRÁNA ${ }^{1}$, David BURIÁNEK ${ }^{3}$, \\ Veronika ŠTĚDRÁ 1 , Lukáš VONDROVIC ${ }^{1,2}$ \\ ${ }^{1}$ Czech Geological Survey, Klárov 3, 11821 Prague 1, Czech Republic; jaroslava.pertoldova@geology.cz \\ ${ }^{2}$ Institute of Petrology and Structural Geology, Charles University, Albertov 6, 12843 Prague 2, Czech Republic \\ ${ }^{3}$ Czech Geological Survey, Leitnerova 22, 65859 Brno, Czech Republic \\ * Corresponding author
}

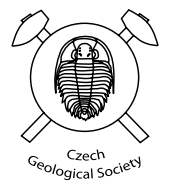

\begin{abstract}
Multidisciplinary research evaluates structural, metamorphic and petrochemical data of selected rock types in different units located in the northeastern part of the Bohemian Massif, Czech Republic: (1) the Strážek Unit in the northeastern part of the Moldanubian Zone, (2) the Svratka and Kutná Hora units correlated with the Orlice-Sněžník Unit in Western Sudetes as well as (3) the Polička, Hlinsko and Zábřeh units belonging to the Teplá-Barrandian Zone. Petrochemical data for metasediments of the Polička, Hlinsko and Zábřeh units are mutually comparable and confirm a lithological affinity to the upper-crustal Teplá-Barrandian Zone. The $\mathrm{FeO}_{t} / \mathrm{MnO}$ ratios in metasediments of the Strážek Unit and the Svratka Unit indicate differences in the origin of sedimentary protolith rocks.

Relict pre-Variscan structures, including extensive migmatization, and high-grade mineral assemblages with peak metamorphic pressures of $\sim 1.4 \mathrm{GPa}$ in skarn bodies, are preserved in the Svratka Unit. The evidence for Palaeo-Variscan (390-355 Ma) HP and UHP events, recorded in the high-grade Kutná Hora and Orlice-Sněžník units, was observed neither in the NE part of the Moldanubian Zone (Strážek Unit) nor the Teplá-Barrandian Zone (Polička and Zábřeh units). The Variscan orogenic event imprinted in the Svratka, Polička and Zábřeh units was the right-lateral slip along WNW-ESE trending shear zones. This deformation was accompanied by metamorphism at $\sim 580-650^{\circ} \mathrm{C}$ and $\sim 0.5-0.7$ $\mathrm{GPa}(352-343 \mathrm{Ma})$ and intrusion of numerous small bodies of syn-deformation calc-alkaline granitoids in the Polička and Zábřeh units. The younger metamorphic fabrics in the northeastern part of the Moldanubian Zone reflect a fast exhumation of deep-seated high-grade complexes at $\sim 340 \mathrm{Ma}$, which was constrained by post-tectonic emplacement of durbachites at $\sim 339 \mathrm{Ma}$.

Metamorphic development in felsic granulites of the Strážek Unit, metamorphosed c. $340 \mathrm{Ma}$ ago at $850^{\circ} \mathrm{C}$ and $1.8 \mathrm{GPa}$, was followed by decompression to $\mathrm{T} \cong 790^{\circ} \mathrm{C}$ and $\mathrm{P}=1.3 \mathrm{GPa}$ and finally $\mathrm{T}=700^{\circ} \mathrm{C}$ and $\mathrm{P}=\sim 0.4 \mathrm{GPa}$. In contrast, Běstvina granulite in the Kutná Hora Unit, with the $\sim 360$ Ma high-grade metamorphism at $800-920{ }^{\circ} \mathrm{C}$ and $1.8-2.1 \mathrm{GPa}$, is free of such a HT-LP overprint. Thus the data indicate that the Svratka and Kutná Hora units, exhibiting numerous mutual differences, should not be considered as belonging to the Moldanubian Zone as they evolved as independent entities. The geochemical data on garnet-clinopyroxene skarns from the Moldanubian Zone, the Svratka and Kutná Hora units do not provide mutually distinguishing features. This is largely due to a very wide compositional variation in rocks interpreted as metamorphosed exhalite with detrital material admixture. Skarns from the Svratka Unit preserve clinopyroxenes with elevated jadeite component $(0.5-24 \mathrm{~mol}$. \%) and prograde compositional zoning in garnet - features obliterated in samples from the Moldanubian Zone and the Kutná Hora Unit.
\end{abstract}

Keywords: Variscides, Bohemian Massif, lithology, structures, metamorphic evolution Received: 11 October 2010; accepted: 21 December 2010; handling editor: V. Kachlik

The online version of this article (doi: 10.3190/jgeosci.083) contains supplementary electronic material.

\section{Introduction}

This paper presents a new interpretation of tectonometamorphic processes and their time relationships in the units located along the northeastern margin of the Moldanubian Zone, Czech Republic. Information on this part of the Bohemian Massif plays an important role in elucidation of its geodynamic development in space and time. Attention is focused on lithological, petrochemical, structural and geochronological data related to the preVariscan, as well as Paleo- and Neo-Variscan evolution of the studied units.

We evaluate the results of our multidisciplinary research performed in different units located in the northeastern part of the Bohemian Massif: (1) The Strážek Unit representing the north-eastern Moldanubian Zone, 


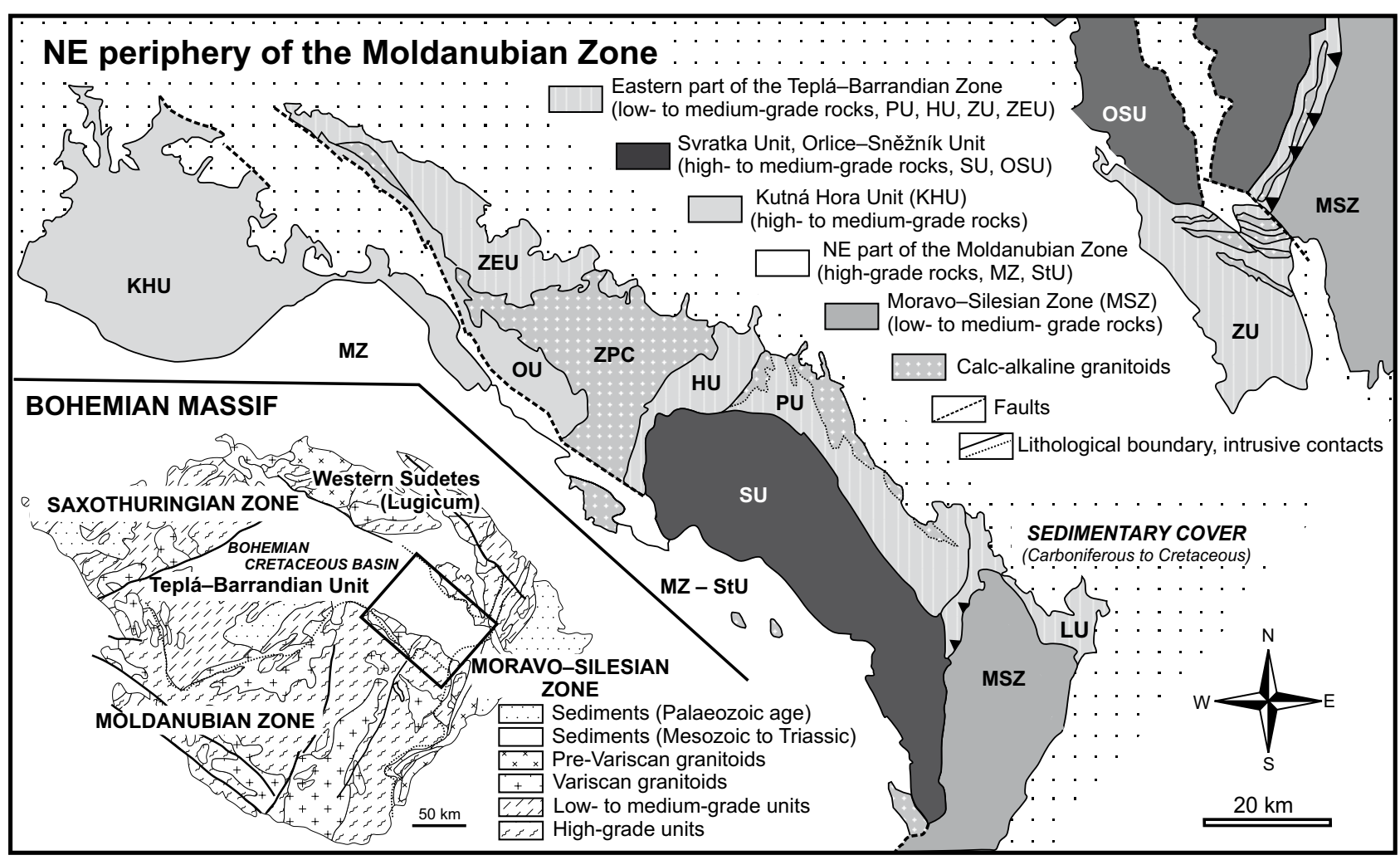

Fig. 1 A simplified geologic map of units along the NE margin of the Moldanubian Zone. Explanations: HU - Hlinsko Unit; KHU - Kutná Hora Unit; LU - Letovice Unit; MSZ - Moravo-Silesian Zone; MZ - Moldanubian Zone; PU - Polička Unit; OSU - Orlice-Sněžník Unit; OU - Oheb Unit; StU - Strážek Unit; SU - Svratka Unit; ZEU - Železné Hory Unit; ZPC - Železné Hory Plutonic Complex; ZU - Zábřeh Unit.

(2) the Svratka, Kutná Hora, Polička, Hlinsko, Zábřeh and Orlice-Sněžník units (Fig. 1). More focussed papers stemming from individual parts of this research were published in the special volume "Geological development of the region at the NE periphery of the Moldanubian Zone, eastern part of the Bohemian Massif" of the Journal of Geosciences (e. g. Buriánek et al. 2009b; Pertoldová et al. 2009; Štědrá and Nahodilová 2009; Verner et al. 2009; Vrána et al. 2009). We also integrate new geological datasets collected during geological mapping in the region (Project No. 6328 "Geological mapping of the Žd'árské Vrchy Protected Landscape Area"). On the basis of new field structural data we characterize regional fabric patterns and tectonic boundaries of the individual units. For lithological and petrochemical correlations were chosen the most telling rock types, i.e., metapelites, migmatites, orthogneisses, metagranites and skarns. Others, such as granulites and eclogites, were compared according to their $\mathrm{P}-\mathrm{T}$ history and ages. The $\mathrm{P}-\mathrm{T}$ estimations from metamorphic assemblages with structural, petrochemical and geochronological data in the selected rocks serve as a basis for unique comparison of lithology and geochemical composition, timing and tectonometamorphic evolution in different units along the north-eastern margin of the Moldanubian Zone. Finally, on the basis of our results and their interpretation, and information published in the literature, we propose a geological model presenting tectonometamorphic processes and their time relationships in the units located along the northeastern margin of the Moldanubian Zone.

\section{Geological setting}

The oldest processes recorded in the studied rocks took place in Neoproterozoic to Early Palaeozoic times $(\sim 570-530 \mathrm{Ma})$, i.e. late during the Cadomian Orogeny, at the periphery of the Gondwana and Avalonia (Hegner and Kröner 2000). The development culminated by the Cambro-Ordovician magmatic stage (e.g. Linnemann et al. 2008). The subsequent Late Devonian to Early Carboniferous collision of Gondwana-derived crustal segments with the Old Red continent resulted in assembly of heterogeneous units and created a new geological framework for the western and central parts of the European continent (e. g. Franke 2000). This Variscan evolution, i.e. subduction of oceanic crust and crustal thickening associated with high-pressure metamorphism, was dated at 390-355 Ma (e. g. in the Orlice-Sněžník and Kutná Hora units; Mazur et al. 2005; R. Nahodilová, personal 
comm.) and Neo-Variscan stage at around $340 \mathrm{Ma}$ (Fiala et al. 1995; Finger et al. 2007; Schulmann et al. 2008, 2009). These processes were followed by fast exhumation of deep-seated rocks and wrench tectonic activity (Kröner et al. 2000 and references therein). These events were connected with juxtaposition of various crustal segments: (1) the Moldanubian Zone comprising a heterogeneous complex of high-grade rocks (for a general review see Fiala et al. 1995; Urban and Synek 1995; Vrána et al. 1995; Schulmann et al. 2008). The term is used here as defined by Fiala et al. (1995), except of the Svratka and the Kutná Hora units - below we present evidence indicating that the latter two units evolved as separate entities; (2) the TepláBarrandian Zone as the upper-crustal segment including unmetamorphosed to medium-grade Neoproterozoic and Lower Palaeozoic volcanosedimentary sequences (e.g. Chaloupský et al. 1995; Zulauf 1997; Drost et al. 2004); (3) the Saxothuringian Zone and Western Sudetes as Neoproterozoic to Lower Palaeozoic rock complexes with tectonically implanted slices of Variscan HP and UHP rocks (Kröner et al. 2001; Mazur et al. 2005).

The units nowadays located at the eastern margin of the Bohemian Massif were thrust over pre-Variscan basement, deformed Late Neoproterozoic granitoids and a tectonically imbricated metasedimentary sequence of Devonian age of the Moravo-Silesian Zone (Schulmann and Gayer 2000).

The area of our interest is located in the north-eastern part of the Bohemian Massif, and is built by several crustal segments with distinct lithology, composition, tectonometamorphic evolution and age. Proposal of the regional geological division of the Czech Republic published by Chlupáč and Štorch (1992) defined various units discussed in the current paper. These are, from the south to the north (Fig. 1): (1) the Strážek Unit representing the NE part of the Moldanubian Zone. It consists of Variscan high-grade rocks, such as migmatites and migmatized paragneisses, with bodies of felsic granulites, ultramafic rocks, amphibolites and skarns (Tajčmanová et al. 2006; Schulmann et al. 2005, 2008); (2) the Kutná Hora Unit subdivided into four sub-units of high-pressure migmatites, orthogneisses, paragneisses and mica schists, enclosing lenses of felsic granulites, garnet peridotites and eclogites. The sub-units recorded an early-Variscan HP tectonometamorphic evolution at around 370-360 Ma (Synek and Oliveriová 1993; Kachlík 1999; Vrána et al. 2005; Medaris et al. 2005, 2006; Nahodilová et al. 2006; Štědrá and Nahodilová 2009; Vrána et al. 2009; Faryad 2009); (3) the Svratka Unit consists of polymetamorphic migmatites, mica schists and paragneisses with amphibolite and skarn intercalations that are cut by bodies of Cambrian metagranites and orthogneisses (Melichar et al. 2008; Verner et al. 2009). The unit exhibits lithological similarities to the Orlice-Sněžník Unit (basement of Western Sudetes; Buriánek et al. 2009b); (4) the structur- ally overlying Polička, Hlinsko and Zábřeh units are low- to medium-grade volcanosedimentary sequences of Neoproterozoic to Lower Palaeozoic age, classified by some authors as the more strongly metamorphosed eastern part of the Teplá-Barrandian Zone (Mísař et al. 1983; Verner et al. 2009) or viewed as relics of an allochthonous cover of the Orlice-Sněžník Unit (e. g. Mazur et al. 2005; Cháb et al. 2010). The Polička, Hlinsko and Zábřeh units contain abundant Variscan calc-alkaline granitoids (Buriánek et al. 2003; Vondrovic and Verner 2008); (5) the high-grade Orlice-Sněžník Unit resembles in terms of its $\mathrm{P}-\mathrm{T}$ development and tectonometamorphic evolution the high-grade Moldanubian Zone. However, the ages of HP-HT metamorphism and the following mid-crustal re-equilibration of the Orlice-Sněžník Unit (dated at c. 360-370 Ma and 345 Ma, respectively) were substantially different (Mazur et al. 2005).

\section{Geological features and metamorphic evolution}

\subsection{Strážek Unit}

The Strážek Unit is composed of Variscan high-grade rocks such as migmatized paragneisses and migmatites with lenses of amphibolites, skarns and tectonic slices of high-pressure felsic granulites (Bory and Drahonín massifs) and upper-mantle ultramafic rocks (Medaris et al. 1995; Tajčmanová et al. 2006; Hanžl et al. 2008a). The Bory granulite Massif carries numerous boudins of upper mantle peridotite, Grt-pyroxenite and eclogite with P-T conditions of equilibration estimated at 3.8-4.8 GPa and 900-1 $000{ }^{\circ} \mathrm{C}$ (Medaris et al. 2005, 2009; Ackerman et al. 2009; Naemura et al. 2009). Felsic granulites of the Strážek Unit preserve early mineral assemblages, indicating HP metamorphic evolution of these rocks under $\mathrm{T}=850{ }^{\circ} \mathrm{C}$ and $\mathrm{P}=1.8 \mathrm{GPa}$ at $340 \pm 1.1 \mathrm{Ma}(\mathrm{U}-\mathrm{Pb}$ on zircon) (Schulmann et al. 2005; Tajčmanová et al. 2006). The subsequent metamorphic events recorded in rocks of the Strážek Unit (partial stages of fast exhumation and re-equilibration) were determined at $\mathrm{T} \cong 790^{\circ} \mathrm{C}$ and $\mathrm{P}=1.3 \mathrm{GPa}$ and, finally, at $\mathrm{T} \cong 700{ }^{\circ} \mathrm{C}$ and $\mathrm{P} \sim 0.4 \mathrm{GPa}$ (Owen and Dostal 1996; Tajčmanová et al. 2006). The overall metamorphic evolution of felsic granulites from Strážek Unit is shown in Fig. 2a (P-T path No. 1).

\subsection{Kutná Hora Unit}

The Kutná Hora Unit (see Fig. 3 in Verner et al. 2009) consists of four different structural sub-units (Synek and Oliveriová 1993; Verner et al. 2009; Štědrá and Nahodilová 2009): (1) polymetamorphic high-pressure Malín migmatites and granulitic Běstvina sub-unit higher in the 

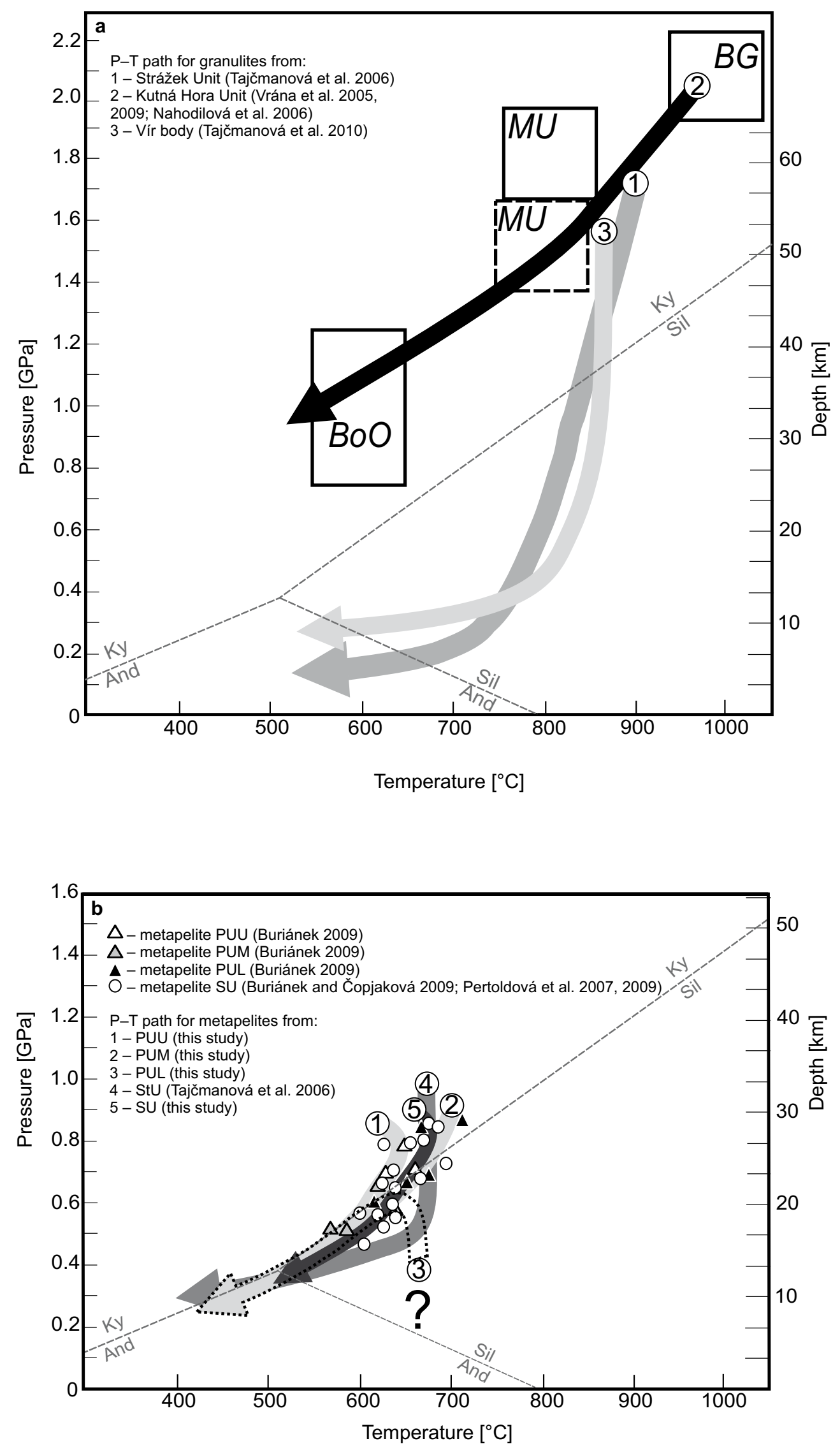

Fig. 2 Summary of published $\mathrm{P}-\mathrm{T}$ paths from the studied region. a: 1 - Granulites in the Strážek Unit, 2 - granulites and other high-pressure rock types in the Kutná Hora Unit (BG - Běstvina granulite, MU - Malín subunit, $\mathrm{BoO}$ - Bohouňovice orthogneiss), 3 - Vír granulite. b: metapelites in the Strážek Unit (StU), Svratka Unit (SU), Upper part of the Polička Unit (PUU), Middle part of the Polička Unit (PUM), Lower part of the Polička Unit (PUL). The $\mathrm{Al}_{2} \mathrm{SiO}_{5}$ univariant curves are according to Holdaway (1971). 


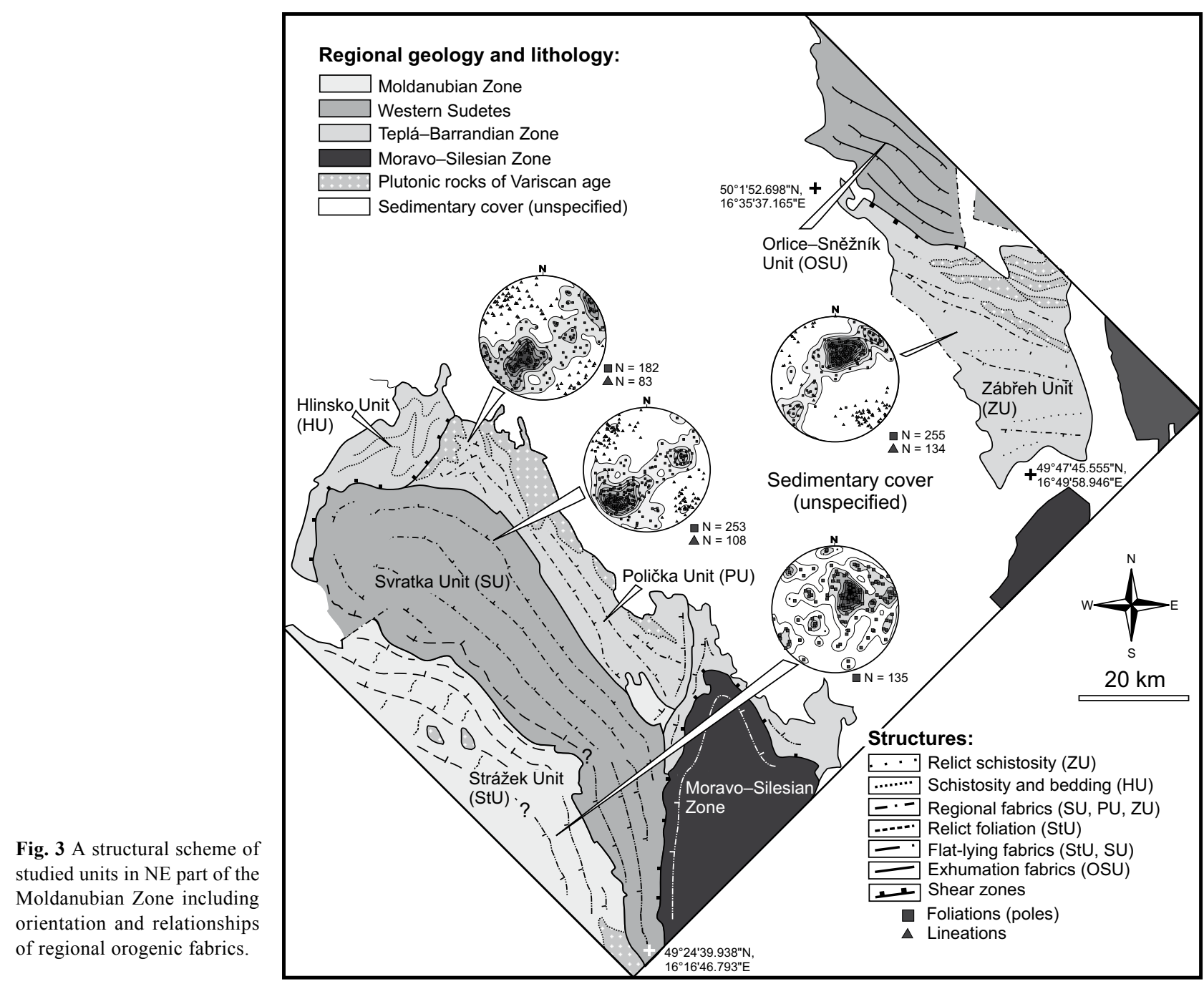

structural sequence, (2) the Kouřim Nappe consisting of orthogneisses and fine-grained leucocratic migmatites, (3) the Mica Schist sub-unit, and (4) the Plaňany sub-unit. The Rataje Mica Schist zone, included by Synek and Oliveriová (1993) in the Kutná Hora Unit, in fact represents a retrogressed marginal part of the Moldanubian Zone (Koutek 1933; Mísař et al. 1983; Kachlík 1999). Several metamorphic phases, based on mineral assemblages and tied to tectonic events, have been defined in the Kutná Hora Unit. The early mineral assemblage evolved under upper mantle conditions in tectonic slices of Grt peridotites, Grt pyroxenites, eclogites and felsic granulites. The Běstvina sub-unit carries numerous boudins of upper mantle garnet peridotite, Grt pyroxenite and eclogite equilibrated at 3-5 $\mathrm{GPa}$ and $850-1100{ }^{\circ} \mathrm{C}$ (Medaris et al. 2006; Faryad 2009). The eclogites in the central part of the Kutná Hora Unit indicate minimum pressures exceeding 2.2-2.3 GPa and temperatures of $c .600-820{ }^{\circ} \mathrm{C}$ (Medaris et al. 2006; Štědrá and Nahodilová 2009). In HP/ HT granulites of the Běstvina sub-unit equilibration took place at $840-920{ }^{\circ} \mathrm{C}$ and $1.8-2.2 \mathrm{GPa}$ (Vrána et al. 2005). Nahodilová et al. (2006) and Faryad (2009) determined the conditions of the retrogression at $705 \pm 97^{\circ} \mathrm{C}$ and 1.4 $\pm 0.2 \mathrm{GPa}$. This event can be possibly correlated with the high-pressure migmatization in the Malín sub-unit under eclogite-facies conditions, succeeded by regional highpressure mylonitic deformation (Synek and Oliveriová 1993; Vrána et al. 2009). The leucogranites intruded in migmatites of the Malín sub-unit were affected by superimposed HP tectonometamorphic event and transformed to Ky-Grt gneisses under a pressure of 0.9 to $1.2 \mathrm{GPa}$ (Synek and Oliveriová 1993; Vrána et al. 2009). Key stages of P-T evolution of HP metamorphic rocks from the Kutná Hora Unit are summarized in Fig. 2a.

\subsection{Svratka Unit}

This unit consists of pre-Variscan polymetamorphic migmatites with elongated bodies of orthogneisses of Cambrian age, mica schists, paragneisses and small 
intercalations of dolomitic marbles, amphibolites and skarns (Melichar 1995; Schulmann et al. 2005; Melichar et al. 2008; Hanžl et al. 2008b). The early, pre-Variscan metamorphic stage resulted in extensive migmatization. It is characterized by prograde garnet zoning in skarns, and corresponded to pressures $\sim 1.4 \mathrm{GPa}$ (Pertoldová et al. 2009). The peak metamorphic conditions during the Variscan orogeny were estimated at $\sim 640-670{ }^{\circ} \mathrm{C}$ and 0.6-0.8 GPa (Buriánek and Čopjaková 2009). This metamorphic event was identified in mica schists by a stable $\mathrm{Ms}+\mathrm{Bt}+\mathrm{Grt}+\mathrm{St}+\mathrm{Ky}$ mineral assemblage. Sillimanite is associated with superimposed deformation at $\sim 580-650{ }^{\circ} \mathrm{C}$ and $0.6 \mathrm{GPa}$ (Buriánek and Čopjaková 2009; Tajčmanová et al. 2010). The overall metamorphic development in metapelites of the Svratka Unit is summarized in Fig. 2b (P-T path No. 5). The age of the regional Variscan tectonometamorphic event in the Svratka Unit is unknown as the published results of ${ }^{40} \mathrm{Ar} /{ }^{39} \mathrm{Ar}$ muscovite dating (from $325 \pm 0.4$ to $331.6 \pm 0.3 \mathrm{Ma}$; Fritz et al. 1996) most likely reflect cooling during the later stages of exhumation.

\subsection{Polička Unit}

The Polička Unit represents probably Neoproterozoic to Lower Palaeozoic volcanosedimentary sequence penetrated by calc-alkaline plutonic rocks dated at $\sim 346 \pm 6 \mathrm{Ma}$ (U-Pb on zircon; Vondrovic and Verner 2008; Vondrovic et al. unpublished data). On the basis of the lithological composition, the Polička Unit can be subdivided into three different parts (Melichar 1995), which are, from south to north: (1) the structurally lowest medium-grained biotite and two-mica paragneisses ( $\pm \mathrm{Grt} \pm \mathrm{Sil})$ with deformed bodies of metagranites, amphibolites, marbles, calc-silicate rocks and an allochthonous Vír felsic granulite massif; (2) middle part consists of a monotonous complex of medium-grained biotite to two-mica paragneisses ( \pm Grt \pm Sil) with abundant calc-silicate nodules and intercalations of metapelites and metaconglomerates; (3) the upper part is composed of mica schist with intercalations of quartzite and paragneiss. Mica schists of the uppermost Polička Unit exhibit the mineral assemblage $\mathrm{Qtz}+\mathrm{Ms}+\mathrm{Bt} \pm \mathrm{Pl} \pm \mathrm{St} \pm \mathrm{Grt} \pm \mathrm{Pl}( \pm \mathrm{Ky}$ in the eastern part of the unit), indicating peak metamorphic conditions of $\mathrm{T} \cong 650^{\circ} \mathrm{C}$ and $\mathrm{P} \cong 0.8 \mathrm{GPa}$ and a retrograde overprint at $660{ }^{\circ} \mathrm{C}$ and $0.7 \mathrm{GPa}$ (Buriánek 2009) (Fig. $2 \mathrm{~b}, \mathrm{P}-\mathrm{T}$ path No. 1 ). In the metapelites of the middle part of the Polička Unit, the mineral assemblage equilibrated at $570-680^{\circ} \mathrm{C}$ and $\sim 0.6 \mathrm{GPa}$; (Fig. $2 \mathrm{~b}, \mathrm{P}-\mathrm{T}$ path No. 2). Relics of sillimanite pseudomorphs after andalusite indicate an older LP metamorphic event (Buriánek et al. 2003). Estimated peak P-T conditions in allochthonous tectonic slices of Vír granulites dated by Tajčmanová et al. (2010) at $\sim 354 \pm 7 \mathrm{Ma}$ (U-Pb on zircon) correspond to $\mathrm{T}=860-1000{ }^{\circ} \mathrm{C}$ and $\mathrm{P}=1.6 \mathrm{GPa}$ (Tajčmanová et al. 2010) (Fig. 2a, P-T path No. 3). These granulites are accompanied by predominating retrogressed orthogneisses. Mineral assemblages in the surrounding metapelites indicate metamorphic conditions of $c .700{ }^{\circ} \mathrm{C}$ and 0.7 $\mathrm{GPa}$, reflecting exhumation of granulites accompanied by partial melting of the metasediments (Buriánek 2009; Buriánek et al. 2009a; Tajčmanová et al. 2010). The U-Pb zircon ages ( $339 \pm 3 \mathrm{Ma}$ and $336.2 \pm 1.2 \mathrm{Ma})$ from granulites of the Vír area and the surrounding amphibolites reflect exhumation of these rocks into a higher crustal level (Tajčmanová et al. 2010). Monazite (U-Pb) dating at 336 $\pm 1 \mathrm{Ma}$ on an orthogneiss-like sample by van Breemen et al. (1982) may indicate a post-peak retrogressive event.

\subsection{Zábřeh Unit}

The Zábřeh Unit is composed of two lithological subunits, low-grade metapelites and metabasites in the south and paragneisses with intercalations of metavolcanites intruded by numerous sheets of calc-alkaline plutonites in the north (Fajst 1976; Hanžl et al. 2000; Buriánek et al. 2003; Verner et al. 2009). The intensity of metamorphism gently increases from the central part to both the south and north. The peak $\mathrm{P}-\mathrm{T}$ conditions in the northern part were estimated at $\sim 0.6 \mathrm{GPa}$ and $\sim 660{ }^{\circ} \mathrm{C}$ (D. Buriánek, unpublished data). In addition, effects of local contact metamorphism in narrow zones along the northern intrusive sheets were identified.

\subsection{Hlinsko Unit}

The Hlinsko Unit, separated by a NNE-SSW trending polyphase shear zone, extends along the northwestern margins of the Svratka and Polička units. It consists of three metasedimentary groups folded in a great synform elongated NNE-SSW. Some weakly metamorphosed rocks carry fossils of Silurian and Late Ordovician age (Štorch and Kraft 2009). Greywackes and metapelites, in places with layers of metavolcanites, were classified as the Hlinsko and Vítanov groups, metapelites with abundant quartzites were assigned to the Mrákotín Series and graywackes to the Rychmburk Series (Vachtl 1962). An anticlockwise P-T path with peak metamorphic conditions of $0.35-0.4 \mathrm{GPa}$ and $600-530{ }^{\circ} \mathrm{C}$ was proposed by Pitra and Guiraud (1996) for more strongly metamorphosed parts of this unit.

\subsection{Orlice-Sněžník Unit}

The Orlice-Sněžník Unit occurs in the SE part of the Western Sudetes (Lugicum) (Kryza et al. 1996; Mazur et al. 2005; Anczkiewicz et al. 2007; Jastrzębski 2009). 
It consists of high- to medium-grade polymetamorphic migmatites and orthogneisses of Cambrian protolith age, with outer envelope of staurolite schists and biotite paragneisses. Migmatites and orthogneisses of the Orlice-Sněžník Unit contain abundant eclogite and granulite bodies (Opletal et al. 1980; Mazur et al. 2005). The latter rocks experienced an Early Variscan HP (UHP) metamorphic evolution followed by a high- to mediumgrade (HT/M-LP) regional tectonometamorphic overprint (Mazur et al. 2005).

\section{Structural patterns}

Rocks of the studied units in the northeastern part of the Bohemian Massif recorded complex and polyphase tectonometamorphic processes, particularly during the Variscan orogeny. The orientation and relationships of regional fabrics briefly described below are shown in Fig. 3.

In the high-grade rocks of the Strážek Unit, the HP(MP)-HT metamorphic stage was followed by rapid exhumation of high-grade rocks. This event was associated with isothermal decompression at high temperatures (Tajčmanová et al. 2010). The regional structural pattern in this unit is formed by subvertical, NNE-SSW to N-S trending metamorphic foliations, containing rare relics of high-grade fabrics, especially in form of minor rootless to isoclinal folds (Tajčmanová et al. 2010). These fabrics were heterogeneously reworked to $\sim \mathrm{NW}-\mathrm{SE}$ to WNW-SSE, flat-lying to gently NNE dipping foliations, in places associated with WNW-ESE plunging mineral lineation. In the Strážek Unit, the formation of this second fabrics is constrained by post-tectonic emplacement of ultrapotassic, Mg-rich granitoids (durbachites) dated by $\mathrm{U}-\mathrm{Pb}$ method on zircon at $339 \pm 2 \mathrm{Ma}$ (A. Gerdes, unpublished data; Verner et al. 2009). In general, second flat-lying fabrics are in northern and north-western parts of the Strážek Unit roughly parallel to the boundary with the adjacent Svratka Unit.

In the Kutná Hora Unit, several stages of regional Variscan tectonometamorphic evolution were identified (e. g. Synek and Oliveriová 1993; Štědrá and Nahodilová 2009; Vrána et al. 2009). During an Early Variscan event, the bodies of mantle peridotites and related UHP rocks, with their relict structures, were tectonically incorporated into gneisses and granulites (Synek and Oliveriová 1993). Faryad (2009) presented an alternative model of crustal and upper-mantle rocks juxtaposition (Machek et al. 2009). Early deformation structures imprinted during the polyphase exhumation of the high-pressure granulites, garnet-kyanite migmatites and other deep-seated rocks of the Kutná Hora Unit are unknown and were at least partly obliterated by younger deformations. To a late generation belong gently to moderately dipping, $\sim \mathrm{NW}$ to $\sim \mathrm{NE}$ trending retrograde planar fabrics developed on a regional scale. This event took place in the stability field of biotite and muscovite in the upper Kourim Nappe, and of garnet + kyanite ( \pm sillimanite) in the Malín and Mica Schist sub-units. This stage was also linked with intense mid-crustal mylonitization and low-angle shearing that resulted in juxtaposition of individual segments of the Kutná Hora Unit and in transformation of alkali-feldspar granite dykes in HP migmatites of the Malín sub-unit into mylonitic garnet-kyanite-bearing orthogneisses (Vrána et al. 2009). Numerous lenses of upper mantle rocks also occur in narrow and steep zones of kyanite-garnet mica schists (Štědrá et al. 2008). Finally, the late tectonic episodes in the Kutná Hora Unit proceeded under the lowtemperature brittle-ductile conditions associated with a syntectonic oriented, and later even random, growth of muscovite (Oliveriová et al. 1995).

In the overlying Svratka Unit, relics of pre-Variscan tectonometamorphic record linked with $\sim$ HP metamorphic conditions $(\mathrm{P}=\sim 1.4 \mathrm{GPa})$ were identified (Pertoldová et al. 2009). In addition, discordant intrusive contacts between Cambrian granites $(515 \pm 9 \mathrm{Ma}, \mathrm{U}-\mathrm{Pb}$ zircon age by Schulmann et al. 2005) and the surrounding migmatites were described by Verner et al. (2009). This finding constrains the upper age limit of pre-Variscan high-pressure metamorphism and migmatization of the Svratka Unit to Cambrian times. The Variscan structural pattern of the Svratka Unit is defined by regional metamorphic foliations dipping steeply to moderately to the $\sim \mathrm{NNW}-\mathrm{NE}$ in its western and central, and steeply to the $\sim \mathrm{SW}$ in its eastern part. These foliations are associated by well-developed stretching lineations (elongated quartz and feldspar aggregates) which plunge under low angles to the $\sim \mathrm{NW}$ or SE (Verner et al. 2009). Kinematic background of these fabrics suggests a polyphase evolution of right-lateral transtensional to transpressional widely-distributed shear zone. In the southern part of the Svratka Unit these regional fabrics were affected by tectonometamorphic overprint associated with minor partial melting and formation of the gently NNE dipping foliation. During the Variscan Orogeny, the Svratka Unit was affected by regional metamorphism reaching only the amphibolite-facies conditions only (Fig. 2b; P-T path 5).

The structural pattern of the overlying Polička Unit is defined by regional metamorphic foliations (pervasive schistosity or compositional banding), which dip steeply to moderately to the NNE-ENE in the central and eastern part, and to the WNW along the western margin of this unit. The foliations bear well-developed, gently plunging NW-SE stretching lineation associated with right-lateral kinematic indicators (Verner et al. 2009). The northern part of The Polička Unit was intruded by numerous bodies of calc-alkaline composition (dated by $\mathrm{U}-\mathrm{Pb}$ method 
on zircon at $352-343 \mathrm{Ma}$; Vondrovic and Verner 2008; L. Vondrovic unpublished data). The transition of magmatic to HT sub-solidus fabrics in regional orientation, mostly parallel to the intrusive contacts, indicate syntectonic emplacement of these intrusions in relation to the main tectonometamorphic event (Verner et al. 2009).

In the northern part of the Zábreh Unit, the regional metamorphic foliations dip moderately to steeply to the $\sim$ SSW and are associated with well-developed stretching lineation which plunges gently to the $\sim \mathrm{ESE}$ or WNW. The intrusive contacts and magmatic to sub-solidus fabrics of abundant calc-alkaline intrusions are roughly parallel to the orientation of the host metamorphic fabrics. The origin of these fabrics in the Zábřeh Unit as well as in the underlying Polička and Svratka units were broadly related with the activity of a regional WNW-ESE directed transpressional to transtensional zone.

Towards the south, the intensity of the transpressional to transtensional fabrics gradually decreases and relics of older low-grade fabrics with a flat-lying orientation could be observed. Finally, the complex of the Zábřeh Unit was affected by sub-vertical shortening. The low-temperature cleavage as well as the axial planes of open folds dipping gently to the SSW were identified. The boundary between the Zábřeh Unit and the adjacent underlying lower to mid- crustal Orlice-Sněžník Unit (Lugicum) is roughly parallel to the regional metamorphic fabrics, however, strongly modified by the Late Variscan right-lateral "Elbe Zone" fault system.

In the upper-crustal Hlinsko Unit several different events in tectonic evolution were identified (Pitra et al. 1994). The bedding planes broadly associated with orientation of low-grade cleavage were affected by folding during polyphase $\sim \mathrm{E}-\mathrm{W}$ shortening and related development of different sets of crenulation cleavages. The last event of $\sim \mathrm{E}-\mathrm{W}$ shortening of metasediments of the Hlinsko Unit resulted in the formation of a regional WNWvergent synclinal structure. The boundary between the upper-crustal Hlinsko Unit and mid-crustal Polička Unit has a character of moderate- to low-temperature NNESSW oriented shear zone. The initial stages of shearing during compression were related to the syntectonic emplacement and subsequent high-temperature deformation of calc-alkaline granitoids of the Miřetín Pluton, recently dated by Vondrovic and Verner (2008, unpublished data) at $345 \pm 5 \mathrm{Ma}$ (U-Pb on zircon).

In the southern part of the high-grade Orlice-Sněžník Unit (eastern part of Lugicum), a set of retrograde mid-crustal fabrics was identified (Mazur et al. 2005). On a regional scale, along the southern margin of the Orlice-Sněžník Unit, the medium-grade compositional banding dips under moderate angles to the SW and to S. These planar fabrics are associated with well-developed $\sim \mathrm{NNW}-\mathrm{SSE}$ to $\mathrm{N}-\mathrm{S}$ plunging stretching lineation and indicators of regional extension.

\section{Lithological and petrochemical comparison of selected rocks}

\subsection{Metapelites and metapsammites}

The metasediments of the studied units experienced a complicated history of polyphase metamorphism and migmatization (Buriánková et al. 2008; Hanžl et al. 2008b), which affected the composition of the original sediments with varying intensity. The Polička, Zabřeh and Hlinsko units represent metasedimentary sequences with a predominance of muscovite-biotite to biotite gneisses and lower grade rocks (Buriánek 2010). As these complexes are largely free of migmatization, the main features of sedimentary protoliths are probably widely preserved and thus can be studied by geochemical methods. The primary data used for construction of the whole-rock geochemical diagrams are stored in electronic appendices 1 and 2 .

In the $\mathrm{K}_{2} \mathrm{O} / \mathrm{Na}_{2} \mathrm{O}$ vs. $\mathrm{SiO}_{2} / \mathrm{Al}_{2} \mathrm{O}_{3}$ (wt. \%) plot of Wimmenauer (1984), gneisses and other metasediments from the Polička, Zábřeh and Hlinsko units form a roughly linear data array mainly in the fields of greywacke and claystone, less frequently mudstone (Fig. 4a).

Overall, the geochemical features of metasediments of the Hlinsko, Zábřeh and Polička units are all mutually comparable. Major- and trace-element data for metasediments from these units present evidence of their affinity to the Bohemicum (Patočka et al. 2003; Drost et al. 2004; Buriánek 2010). Manganese-rich metasediments from the Hlinsko Unit (Fig. 4c) can be interpreted as metapelites and metapsammites deposited around submarine springs (Buriánek and Otava 2007). The chemical composition of Polička Unit metasediments probably resulted from mixing between arc and continental-derived detritus. The elevated $\mathrm{La} / \mathrm{Th}$ ratio, together with decreased $\mathrm{Th} / \mathrm{Sc}$ and $\mathrm{Zr} / \mathrm{Sc}$ ratios, in the Hlinsko Unit sediments indicate a larger input from the volcanic arc source (Fig. 4d). Indeed, tuffitic horizons were indentified in the Vítanov Formation of the Hlinsko Unit.

Biotite to muscovite-biotite migmatites, gneisses or mica schists are predominant in the Strážek and Svratka units. Because of probable modifications due to migmatization (e.g., Inger and Harris 1993; Bea 1996), some geochemical features of these rocks are discussed separately. Shortage of modern whole-rock analyses from the Kutná Hora Unit prevents correlation for this unit.

In the $\mathrm{K}_{2} \mathrm{O} / \mathrm{Na}_{2} \mathrm{O}$ vs. $\mathrm{SiO}_{2} / \mathrm{Al}_{2} \mathrm{O}_{3}$ (wt. \%) plot of Wimmenauer (1984), migmatites and gneisses fall mainly along the greywacke-arkose boundary (Fig. 5a). Mica schists of Svratka Unit almost form a separate field with lower $\mathrm{SiO}_{2} / \mathrm{Al}_{2} \mathrm{O}_{3}$ and increased $\mathrm{K}_{2} \mathrm{O} / \mathrm{Na}_{2} \mathrm{O}$ values, along the boundary between the fields of arkose and claystone. In the $\mathrm{TiO}_{2}$ vs $\mathrm{FeO}_{\mathrm{t}} / \mathrm{MnO}_{\mathrm{t}}$ diagram (Fig. 5b), the Strážek 

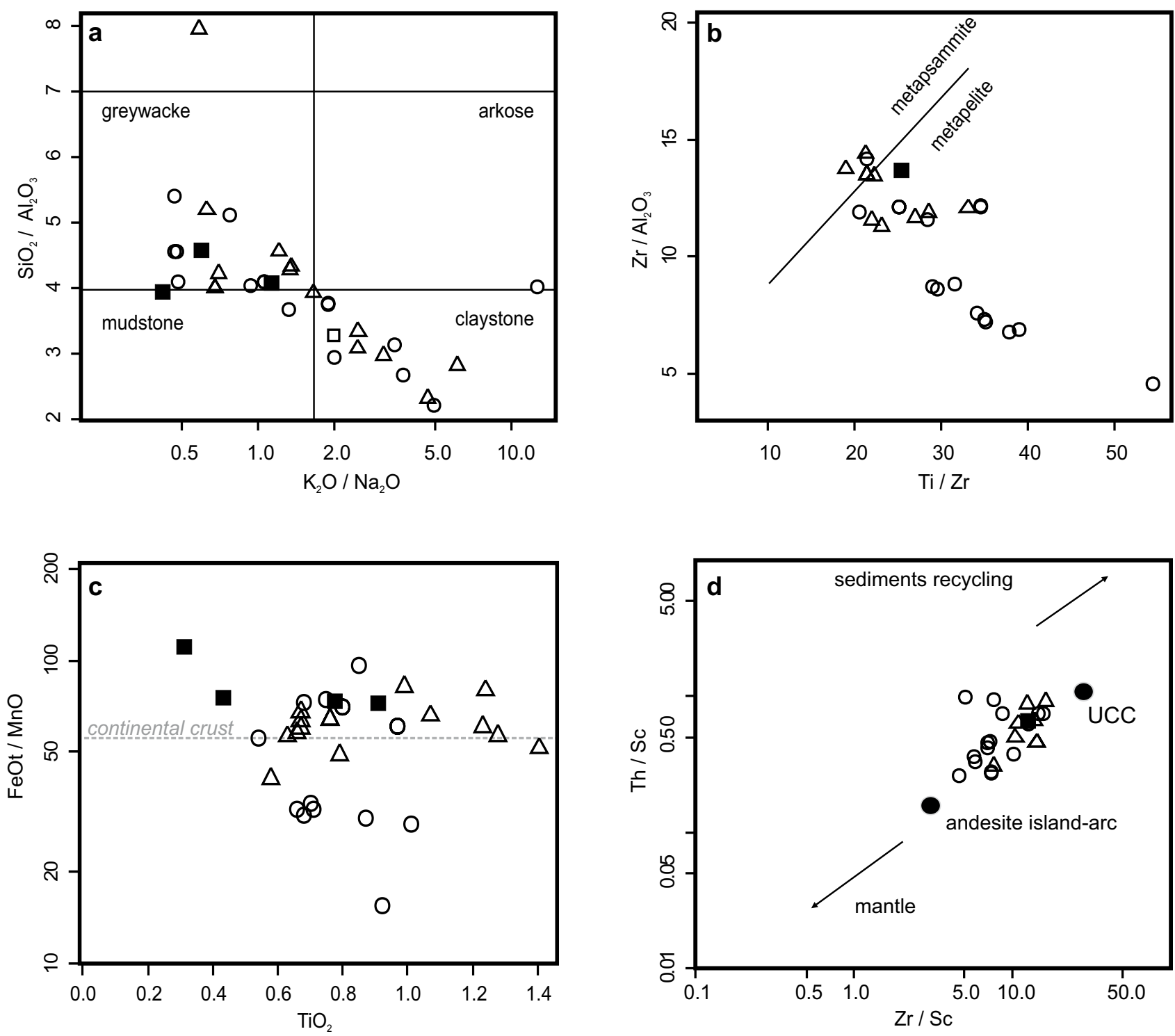

\section{O Hlinsko Unit $\Delta$ Polička Unit $\quad$ Zábřeh Unit}

Fig. 4 Whole-rock geochemistry of paragneisses in the Polička, Hlinsko and Zábřeh units. a $-\mathrm{K}_{2} \mathrm{O} / \mathrm{Na}_{2} \mathrm{O}$ vs. $\mathrm{SiO}_{2} / \mathrm{Al}_{2} \mathrm{O}_{3}(\mathrm{Wimmenauer} 1984)$; b - Ti/Zr vs. $\mathrm{Zr} / \mathrm{Al}_{2} \mathrm{O}_{3}$ (Roser and Nathan 1997); c - $\mathrm{TiO}_{2}$ vs. FeOt/MnO (FeOt/MnO ratio typical for the continental crust according Maynard 2005); d $-\mathrm{Zr} / \mathrm{Sc}$ vs Th/Sc plot (after McLennan et al. 1990, 1993). UCC - Upper Continental Crust. Primary data used for construction of the whole-rock geochemical diagrams are stored in electronic Appendix 1.

Unit samples plot along an approximately horizontal line near the crustal $\mathrm{FeOt} / \mathrm{MnO}$ value (c. 55 - Quin and Humayun 2008; Lewis 2004). On the other hand, the migmatites and, in particular, mica schists and paragneisses from Svratka Unit exhibit dramatic deviations from the normal crustal $\mathrm{FeOt} / \mathrm{MnO}$ ratios. Migmatites from Svratka Unit display a wide variation (6-100) and mica schists plot at higher still $\mathrm{FeOt} / \mathrm{MnO}$ values (c. 100-190). These relations indicate a very high contrast in the geochemistry of the two units.

The $\mathrm{Zr} / \mathrm{Hf}$ ratio in the rocks of the Svratka and Strážek units is 32 and 42 respectively, as indicated by linear fits.
This situation suggests supply of geochemically more evolved material in the course of deposition of sediments that became protolith to the metamorphic rocks of the Svratka Unit (Dostal and Chatterjee 2000; Linnen and Keppler 2002).

\subsection{Neoproterozoic and Early Paleozoic orthogneisses and metagranites}

Orthogneisses to metagranites are relatively common rock-types in the units along the NE margin of the Moldanubian Zone. Data on the lithological composition and 

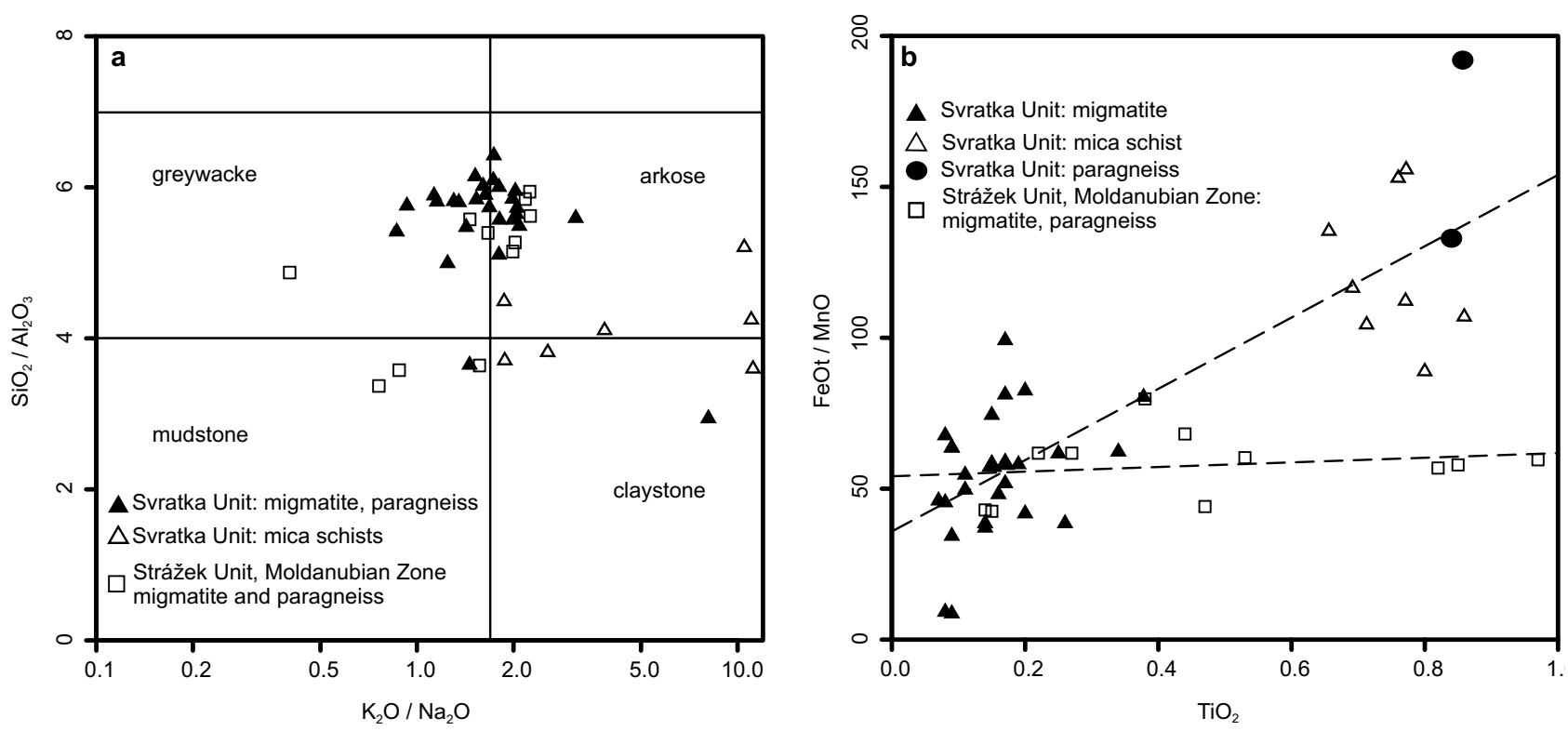

Fig. 5 Whole-rock geochemistry of paragneisses and migmatites in the Svratka and Strážek units. a $-\mathrm{K}_{2} \mathrm{O} / \mathrm{Na}_{2} \mathrm{O}$ vs. $\mathrm{SiO}_{2} / \mathrm{Al}_{2} \mathrm{O}_{3}$ (Wimmenauer 1984); b $-\mathrm{TiO}_{2}$ vs. FeOt/MnO plot. Linear fit is indicated by dashed lines separately for samples from the Strážek and Svratka units respectivelly. Primary data used for construction of the whole-rock geochemical diagrams are stored in electronic Appendix 2.

geodynamic evolution of rocks in the Svratka and the Orlice-Sněžník units were used and compared.

The radiometric dating of metagranites from the Svratka Unit (conventional U-Pb method on zircon) revealed three different stages in the evolution of these rocks (Schulmann et al. 2005): (I) $1932 \pm 7 \mathrm{Ma}$ - inherited (upper intercept) age indicates a period of partial melting of the Palaeoproterozoic basement; (II) the date $515 \pm 9$ Ma suggests granite intrusion and crystallization; (III) the age of c. 340 Ma reflects a period of the Variscan regional tectonometamorphic overprint. For comparison, granitic protolith geochronology data for the Orlice-Sněžník orthogneisses include single zircon $\mathrm{Pb}-\mathrm{Pb}$ ages of 515-503 $\mathrm{Ma}$ (Kröner et al. 2001) and $\mathrm{U}-\mathrm{Pb}$ ages of 503-488 Ma (Mazur et al. 2010).

In the Svratka and Orlice-Sněžník units, the studied meta-granitic rocks are very similar in petrology, as well as mineral and whole-rock chemical composition (Buriánek et al. 2009b). Differences in microstructures and textures relate to distinct geodynamic evolution of the individual bodies. In general, primary magmatic minerals are recrystallized into a mosaic of K-feldspar, albitic plagioclase, quartz, biotite and muscovite aggregates. Apatite, zircon, monazite and ilmenite are common accessories. The whole-rock compositions of samples from the Svratka and Orlice-Sněžník units are similar and contain relatively high $\mathrm{SiO}_{2}(\sim 76$ wt. \%), the $\mathrm{A} / \mathrm{CNK}$ ratio ranges between 1.0 and $1.3, \mathrm{~K}_{2} \mathrm{O}+\mathrm{Na}_{2} \mathrm{O}$ values from 7.2 to 8.8 wt. $\%$ and $\mathrm{K}_{2} \mathrm{O} / \mathrm{Na}_{2} \mathrm{O}$ ratios reach 1.4-2.4. These data indicate highly potassic to shoshonitic characteristics of the studied rocks. The rocks are relatively poor in $\mathrm{Ba}$, $\mathrm{Nb}, \mathrm{Ta}, \mathrm{Sr}, \mathrm{Hf}$ and $\mathrm{Zr}$, and rich in $\mathrm{Cs}, \mathrm{Rb}, \mathrm{Th}, \mathrm{U}, \mathrm{K}$ and
HREE (Buriánek et al. 2009b). In general, the genesis of the protolith to the orthogneisses to metagranites from the Svratka and Orlice-Sněžník units can be interpreted as being a result of partial melting of a similar continental crust at the time of the Cambrian extensional event. During the ascent and emplacement, these rocks developed by moderate degrees of melt fractionation (Buriánek et al. 2009b).

\subsection{Eclogites and metabasites}

Most previously published reports on eclogites and other metabasites in the Kutná Hora Unit were focused on a rigid block of the Běstvina granulite (Medaris et al. 2005, 2006; Faryad 2009). The eclogite-bearing inner part of Kutná Hora Unit is an area roughly corresponding to the Inner Mica Schist Zone sensu Synek and Oliveriová (1993) and its tectonic contact with the high-grade Malín Unit (Losert 1967).

Eclogites in the inner part of the Kutná Hora Unit, along with associated garnet peridotites, occur in mylonitized biotite-muscovite gneisses and mica schists, indicating the character of a deep-seated shear zone (Paděra 1972; Medaris et al. 2005). The zone played an important role in incorporation of the lower-crustal and mantle-derived rocks to upper crustal levels. Several eclogite and Cpx-bearing intermediate rock occurrences have been newly described in the inner part of Kutná Hora Unit near Roztěž, Bořetice and Miškovice (Štědrá and Nahodilová 2009). The REE patterns indicate a lower crustal rather than a mantle source for these HP rocks. The $\mathrm{P}-\mathrm{T}$ calculations yielded minimum pressures above 
Tab. 1 Summary of $\mathrm{P}-\mathrm{T}$ data $\left({ }^{\circ} \mathrm{C} / \mathrm{GPa}\right)$ from eclogites, peridotites and amphibolites of the Kutná Hora Unit and the Strážek Unit (Moldanubian Zone)

\begin{tabular}{|c|c|c|c|c|c|c|c|c|}
\hline Unit & & & & Kutná $\mathbf{H}$ & Hora Unit & & & \\
\hline Locality & Bořetice blocks & Roztěž & Poličany & Ratboř & Plaňany & Bečváry & Stříbrná Skalice & Žehušice \\
\hline Rock type & $\begin{array}{c}\text { Ky } \\
\text { eclogite }\end{array}$ & Eclogite & Eclogite & $\begin{array}{c}\text { Grt } \\
\text { peridotite }\end{array}$ & $\begin{array}{c}\text { Grt } \\
\text { lherzolite }\end{array}$ & $\begin{array}{c}\text { Grt } \\
\text { peridotite }\end{array}$ & Amphibolite & $\begin{array}{c}\text { Grt } \\
\text { amphibolite }\end{array}$ \\
\hline Crystallization & & & & $820-890$ & $1120-1190$ & $845 / 4.1$ & & \\
\hline HP stage (min. P) & $620 / 2.0860 / 2.3$ & $720-810 / 2.2-2.3$ & & & & & $620-710 / 0.9-1.2$ & $606 / 1.3$ \\
\hline HT stage & & $890 / 1.3$ & & & & & & \\
\hline Retrograde stage & & & $550-600 / 0.5$ & & & & & \\
\hline Age determination & $338 \pm 8 \mathrm{Ma}^{* *}$ & & & & & $377 \pm 20 \mathrm{Ma}^{*}$ & & \\
\hline References & SN2009 & SN2009 & NV1996 & M2006 & S2007 & M2005 & K1999 & NV1996 \\
\hline Unit & & Kutná $\mathbf{F}$ & Hora Unit - & Běstvina & & & Moldanut & bian Zone \\
\hline Locality & Spačice & Spačice & Spačice & Spačice & Úhrov & Úhrov & Bída & Borek \\
\hline Rock type & $\begin{array}{c}\text { Ky } \\
\text { eclogite }\end{array}$ & $\begin{array}{c}\text { Qtz } \\
\text { eclogite }\end{array}$ & $\begin{array}{c}\text { Grt } \\
\text { peridotite }\end{array}$ & $\begin{array}{c}\text { Ky } \\
\text { eclogite }\end{array}$ & $\begin{array}{c}\text { Grt } \\
\text { peridotite }\end{array}$ & $\begin{array}{c}\text { Ky } \\
\text { eclogite }\end{array}$ & Eclogite & Eclogite \\
\hline Crystallization & & & & & $1170 / 4.4$ & & & \\
\hline HP stage $(\min$. P) & $830-920 / 2.3-2.5$ & $1160-1180 / 1.7-1.9$ & $950 / 4.5$ & $960 / 3.4$ & & $930 / 2.5$ & $660-820 / 1.9-2.3$ & $650 / 1.4-1.5$ \\
\hline HT stage & & & & & & & & \\
\hline Retrograde stage & & & & & & & & \\
\hline Age determination & & & & & & $344 \pm 6 \mathrm{Ma}^{* *}$ & & \\
\hline References & SN2009 & M1998 & WF2009 & WF2009 & M2005 & S2009, M2006 & SN2009 & M1998, M2005 \\
\hline
\end{tabular}

Geothermobarometry references:

SN2009 - Štědrá and Nahodilová (2009); M1998, M2005, M2006 - Medaris et al. (1998, 2005, 2006); NV1996 - Novák and Vrbová (1994);

K1999 - Kachlík (1999); S2007 - Pertoldová et al. (2007); WF2009 - Faryad (2009)

Sm-Nd geochronology references:

* - Beard et al. (1992)

** - Medaris et al. (1995)

2.15-2.3 GPa and temperatures of $c .600-650^{\circ} \mathrm{C}$, and in some cases $720-820^{\circ} \mathrm{C}$, for the peak of metamorphism (Tab. 1) (Štědrá and Nahodilová 2009). Although partially affected by thermal overprint and retrogression, the eclogite samples from this part of the Kutná Hora Unit clearly record a prograde metamorphic path and can be thus compared in this respect with some eclogites in the Běstvina Unit (Medaris at al. 2006; Faryad 2009).

A high-pressure mineral assemblage and peak pressures recorded in one sample of eclogite from the Strážek Unit (Moldanubian Zone) compares to the highest pressures found in the studied area along the Kutná Hora Unit-Moldanubian Zone boundary $(\mathrm{P}>2.0 \mathrm{GPa}$, $\mathrm{T}=700-750{ }^{\circ} \mathrm{C}$ ). On the other hand, the Borek eclogite equilibrated under less extreme metamorphic conditions (Medaris et al. 1998).

\subsection{Skarns}

Skarns in the Svratka Unit, in the neighbouring part of the Moldanubian Zone (Strážek Unit) and in the Kutná Hora Unit form competent lenses and layers in gneisses and migmatites and preserve some early deformation struc- tures. The major minerals are garnet and clinopyroxene. The garnet composition corresponds predominantly to the grossular-almandine-andradite series $\left(\mathrm{Grs}_{75-21}, \mathrm{Alm}_{78-25}\right.$, $\left.\mathrm{Adr}_{65-0}, \mathrm{Sps}_{23-0} \operatorname{Prp}_{7-0} ; \mathrm{X}_{\mathrm{Fe}}=0.95-1.00\right)$, clinopyroxene belongs mostly to the hedenbergite group. The content of the jadeite component is notably increased only in samples from the Svratka Unit (0.5-24 mol. \%). Garnets in skarns from the Svratka Unit exhibit well-defined prograde compositional zoning and, together with variation in the jadeite component in pyroxenes and reaction textures, recorded at least three metamorphic episodes, similarly to their host rocks. Garnet compositions indicating peak pressure conditions of metamorphism in skarns in the Strážek Unit are not preserved and the chemical zoning of garnets shows exclusively a retrograde evolution imprint. The oxygen and fluorine fugacities were probably increased in some garnets, but only locally. Although the chemically homogeneous compositions of individual generations of clinopyroxene and epidote do not reflect the prograde and retrograde events in skarns from the Kutná Hora Unit, a prograde compositional zoning in some garnets was observed (Pertoldová et al. 
Tab. 2 Summary of petrological results from skarns in the Svratka Unit, the Moldanubian Zone and the Kutná Hora Unit (Pertoldová at al. 2009)

\begin{tabular}{|c|c|c|c|c|c|c|}
\hline \multirow{2}{*}{ unit } & \multirow{2}{*}{ skarn type } & \multicolumn{4}{|c|}{ minerals } & \multirow{2}{*}{ note } \\
\hline & & rock-forming & minor & accesoric & secondary & \\
\hline 营 & $\begin{array}{c}\text { Grt-Cpx, Cpx-Grt, } \\
\text { garnetite, Cpx } \\
\text { skarn, Grt-Hbl, } \\
\text { Gru-Cpx }\end{array}$ & $\begin{array}{c}\operatorname{Grt}\left(\mathrm{Grs}_{21-44} \operatorname{Alm}_{25-78}\right. \\
\left.\operatorname{Sps}_{0-23} \operatorname{Adr}_{0-12} \operatorname{Prp}_{0.5-7}\right) \\
\text { Cpx }\end{array}$ & $\begin{array}{l}\text { Qtz, Pl, Ep, } \\
\quad \text { Mag }\end{array}$ & $\begin{array}{c}\text { Zrn, Ttn, Aln, } \\
\text { Ap, Ilm, Ccp, Au, } \\
\text { Py, native Bi }\end{array}$ & $\mathrm{Hbl}, \mathrm{Pl}$ & $\begin{array}{l}\text { Garnets show prograde compositional zoning. } \\
\text { Decompression textures: Ttn } \rightarrow \text { Ttn-Plg sym- } \\
\text { plectite, Grt } \rightarrow \text { Hbl-Plg symplectite, Cpx } \rightarrow \mathrm{Cpx}- \\
\text { Plg symplectite. The content of jadeite compo- } \\
\text { nent in Cpx is } 0.5-24 \mathrm{~mol} \% \text {. }\end{array}$ \\
\hline 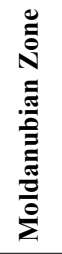 & $\begin{array}{c}\text { Grt-Cpx, Cpx-Grt, } \\
\text { garnetite, Cpx, } \\
\text { Mag with Hbl }\end{array}$ & $\begin{array}{c}\text { older } \operatorname{Grt}_{\left(\mathrm{Grs}_{74-67}\right.} \\
\left.\text { Alm }{ }_{9-12} \mathrm{Adr}_{15-18}\right), \mathrm{Cpx}, \\
\text { younger } \mathrm{Grt}\left(\mathrm{Grs}_{34-35}\right. \\
\left.\mathrm{Alm}_{6-8} \mathrm{Sps}_{4} \mathrm{Adr}_{53-54}\right)\end{array}$ & $\begin{array}{l}\text { Qtz, Pl, Ep, } \\
\text { Mag, Czo }\end{array}$ & $\begin{array}{l}\text { Ttn, Ap, native } \\
\text { Bi, Py, Po }\end{array}$ & $\mathrm{Hbl}, \mathrm{Pl}$ & $\begin{array}{l}\text { Garnets show weak retrograde zoning. Younger } \\
\text { Grt rich in Adr fills fractures in older Grt. }\end{array}$ \\
\hline 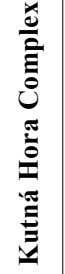 & $\begin{array}{c}\text { Grt-Cpx, Cpx-Grt, } \\
\text { garnetite, Cpx with } \\
\text { Grt }\end{array}$ & $\begin{array}{l}\text { Grt }\left(\mathrm{Grs}_{50-75} \operatorname{Alm}_{24-15}\right. \\
\left.\operatorname{Sps}_{2-0} \operatorname{Adr}_{31-9} \operatorname{Prp}_{1-3}\right) \\
\operatorname{Grt}_{\left(\operatorname{Grs}_{24-65} \operatorname{Alm}_{9-0}\right.} \\
\left.\operatorname{Sps}_{4-0} \operatorname{Adr}_{65-33}\right), \mathrm{Cpx} \\
\text { Ep }\end{array}$ & Mag, Pl & $\begin{array}{l}\text { Ttn, Aln, Ap, } \\
\text { cerite, } \\
\text { hydrogrossular }\end{array}$ & Grt, Ep, Hbl & $\begin{array}{l}\text { Two types of garnet. Both are characterized by } \\
\text { inverse variation in the Grs and And compo- } \\
\text { nents. Grt and Cpx show weak prograde zoning. } \\
\text { Four generations of Ep and three generations of } \\
\text { Cpx. Some Ep are enriched in REE. }\end{array}$ \\
\hline
\end{tabular}

2009). A summary of the petrological data for skarns is presented in Tab. 2.

Altogether 59 whole-rock samples were used for major- and trace-element analyses of skarns in the studied units (Pertoldová et al. 2009). Skarns from the Svratka Unit are highly variable in abundances of major and trace elements (35-55 wt. \% $\mathrm{SiO}_{2}, 1-18 \% \mathrm{Al}_{2} \mathrm{O}_{3}, 1-23$ $\% \mathrm{CaO}, 2-47 \% \mathrm{Fe}_{2} \mathrm{O}_{3}$ and 2-8 \% $\mathrm{MgO}$ ). Seven samples out of 30 have positive Eu anomaly and low total REE contents. Major elements in skarns from the Moldanubian Zone exhibit a wide variation: $20-60$ wt. $\% \mathrm{SiO}_{2}, 1-17 \%$ $\mathrm{Al}_{2} \mathrm{O}_{3}, 5-30 \% \mathrm{CaO}, 1-66 \% \mathrm{Fe}_{2} \mathrm{O}_{3}$ and $0.5-14 \% \mathrm{MgO}$. $\mathrm{The} \mathrm{Eu} / \mathrm{Eu}^{*}$ ratios cover a wide range of 0.5 to 3.5 ; the majority of samples are characterised by values near 1.0. The highest $\mathrm{Eu} / \mathrm{Eu}^{*}$ values are characteristic of samples with low $\Sigma$ REE.

Samples from the Kutná Hora Unit represent mainly Grt-Cpx assemblages with variable contents of the major elements: $22-55$ wt. $\% \mathrm{SiO}_{2}, 2-14 \% \mathrm{Al}_{2} \mathrm{O}_{3}, 14-31 \%$ $\mathrm{CaO}, 2-58 \% \mathrm{Fe}_{2} \mathrm{O}_{3}$ and $0.5-4 \% \mathrm{MgO}$. The abundances of trace elements are variable, both for the individual localities and for the individual samples.

\section{Discussion and conclusions}

On the basis of the summarized petrological, lithologi$\mathrm{cal}$, geochemical and structural data sets, we present an interpretation of the broadly discussed geodynamic evolution and regional classification of various crustal units bordering the northeastern part of the Moldanubian Zone (Fig. 6).

\subsection{Lithology and geochemistry}

\subsubsection{Metasediments}

Metasediments from Polička, Zábřeh (eastern part) and Strážek units have $\mathrm{FeOt} / \mathrm{MnO}$ ratios typical of the continental crust (Maynard 2005). The contrast in $\mathrm{FeOt} / \mathrm{MnO}$ values in metasediments from Svratka and Hlinsko units indicate a role of specific redox conditions at the time of deposition and diagenesis of protolith sediments. Details of the scenario are not well understood yet. In any case, the differences in the $\mathrm{FeOt} / \mathrm{MnO}$ values indicate a major contrast in deposition conditions of the protolith sediments of the Svratka and Strážek units. Both weakly oxidizing or weakly reducing conditions can induce a lower Mn content in seawater (Maynard 2005).

Sample sets for individual units exhibit characteristic pattern in the high-field-strength elements contents. Low $\mathrm{Th} / \mathrm{Sc}$ and $\mathrm{Zr} / \mathrm{Sc}$ ratios and LREE contents are typical signatures of metasediments from the Hlinsko Unit and indicate a considerable proportion of igneous-arc material in the sedimentary protolith. Metasediments of the Polička and Zábřeh units probably represent mixing of arc- and continent-derived material and show affinity to the Hlinsko Unit.

\subsubsection{Orthogneisses}

As shown by Buriánek et al. (2009b), protoliths to orthogneisses and metagranites in the Svratka and the Orlice-Sněžník units were likely to have originated by melting of similar crustal rocks and evolved by analogous 


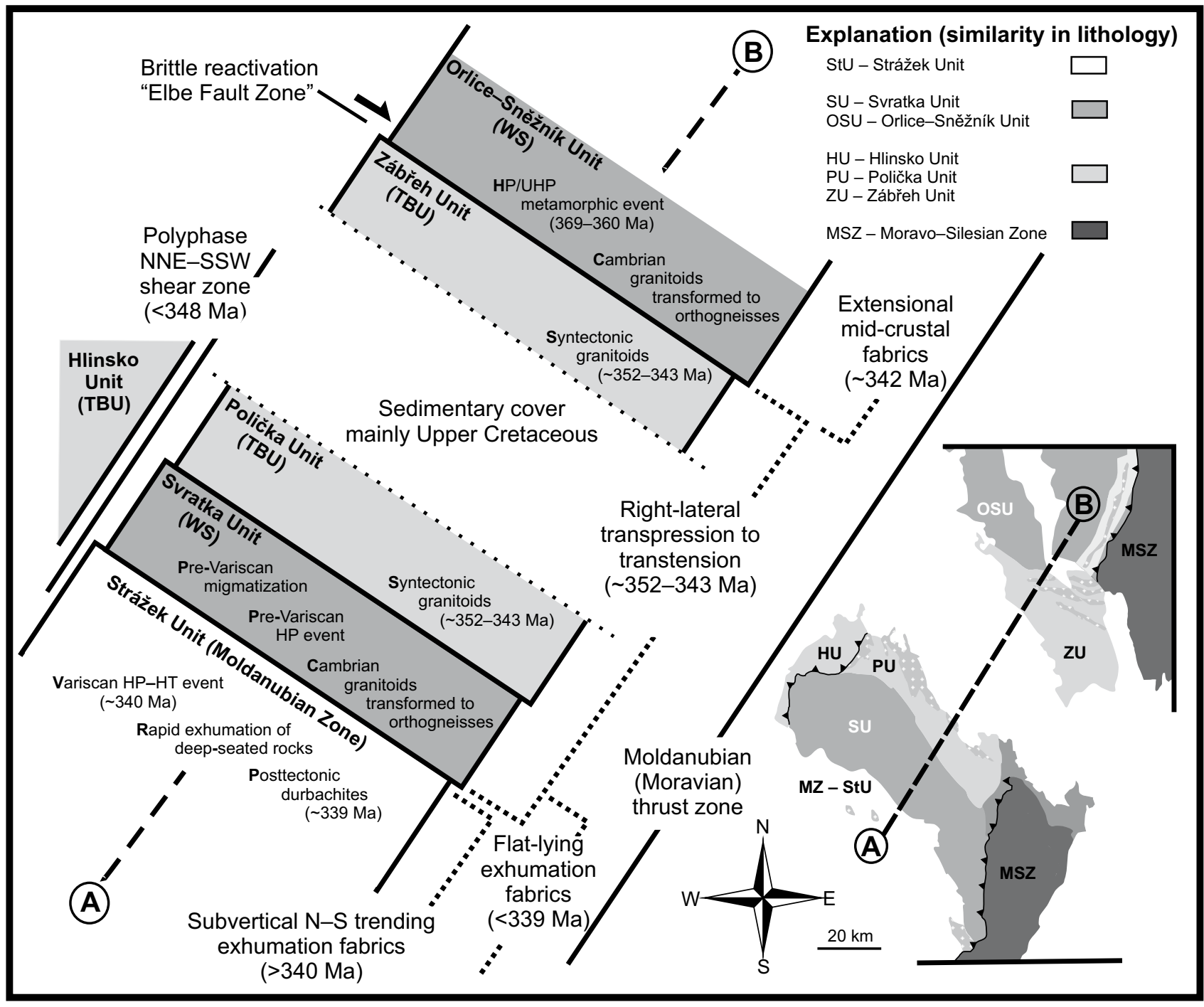

Fig. 6 Schematic relations of units bordering the Moldanubian Zone in NE Bohemia.

processes during Cambrian magmatic event 530-515 Ma ago (U-Pb on zircon) (Kröner et al. 2001; Štípská et al. 2004; Schulmann et al. 2005). The rock-forming minerals of the studied rocks were affected by Variscan deformation and metamorphic recrystallization under $\sim \mathrm{MP}-\mathrm{MT}$ conditions at $\sim 350-330 \mathrm{Ma}$ (Buriánek et al. 2009b). Based on published petrochemical data on different types of Cambrian orthogneisses from the Bohemian part of the Moldanubian Zone (e. g. Vrána and Kröner 1995; Breiter et al. 2005), these orthogneisses seem essentially different from the studied metaigneous rocks in the Svratka and Orlice-Sněžník units.

\subsubsection{Granulites}

Granulites are high-pressure rocks equilibrated in fact under eclogite-facies conditions $(\mathrm{P}=1.8-2.2 \mathrm{GPa})$ at high temperatures $\left(\mathrm{T}=800-1000^{\circ} \mathrm{C}\right)$. Rock-types with granite composition (Ky-Grt-Pl-Kfs (mesoperthite)-Qtz $\pm \mathrm{Bt}$ ) strongly predominate in all the granulite massifs listed above. However, aberrant compositions are also present; e.g. in the Běstvina body these are rocks of paragneiss composition (rich in Grt, Ky and primary Bt, with greywacke-like chemistry), and rare albite-K-feldspar felsic granulites (Vrána et al. 2005, 2009). Granulites form small bodies up to $10 \mathrm{~km}$ long, tectonically incorporated in paragneiss-migmatite host-rocks, the latter carrying mineral assemblages indicating significantly lower pressures and temperatures of equilibration. It is of particular interest that granulites in individual units feature contrasting $\mathrm{P}-\mathrm{T}$ paths during exhumation-related decompression (Tab. 3). Granulites in the Strážek Unit (Drahonín and Bory massifs) exhibit prominent HT-MP/ LP decompression recrystallization (Owen and Dostal 1996; Tajčmanová et al. 2006), which however lacks in the Kutná Hora Unit (Běstvina Massif) (Vrána et al. 2005, 
Tab. 3 Main features of granulite massifs in the studied area

\begin{tabular}{|c|c|c|c|c|c|c|}
\hline Massif & Dimensions & Geological unit & Peak $\mathrm{P}-\mathrm{T}$ conditions & Decompression $\mathrm{P}-\mathrm{T}$ & Age determination* & Main references \\
\hline Běstvina & $9 \times 3 \mathrm{~km}$ & Kutná Hora Unit & $1.8-2.2 \mathrm{GPa}, 800-900{ }^{\circ} \mathrm{C}$ & $\begin{array}{l}1.4 \mathrm{GPa}, c .710^{\circ} \mathrm{C}, \\
\text { decompression in } \\
\text { Ky field }\end{array}$ & $\mathrm{U}-\mathrm{Pb}$ zircon $360 \pm 5.3 \mathrm{Ma}^{* *}$ & $\begin{array}{l}\text { Vrána et al. (2005), } \\
\text { Nahodilová et al. } \\
(2006)\end{array}$ \\
\hline Drahonín & $4 \times 1.5 \mathrm{~km}$ & Strážek Unit (MZ) & $1.8 \mathrm{GPa}, c .850^{\circ} \mathrm{C}$ & $\begin{array}{l}\text { c. } 0.4 \mathrm{GPa}, c .700^{\circ} \mathrm{C} \text {, } \\
\text { inversion } \mathrm{Ky} \rightarrow \mathrm{Sil}\end{array}$ & $\mathrm{U}-\mathrm{Pb}$ zircon $340 \pm 1.1 \mathrm{Ma}$ & $\begin{array}{l}\text { Schulmann } \\
\text { et al. (2005), } \\
\text { Tajčmanová et al. } \\
(2006)\end{array}$ \\
\hline Bory & $10 \times 3.5 \mathrm{~km}$ & Strážek Unit (MZ) & $1.6 \mathrm{GPa}, 850-900{ }^{\circ} \mathrm{C}$ & $\begin{array}{l}\text { widespread inversion } \\
\text { Ky } \rightarrow \text { Sil } \pm \text { hercynite } \\
\text { and newly formed } \\
\text { Crd }\end{array}$ & $\mathrm{U}-\mathrm{Pb}$ zircon $347+9 /-10 \mathrm{Ma}$ & $\begin{array}{l}\text { Kröner et al. } \\
(1988), \text { Staňková } \\
(1982), \\
\text { Kotková et al. } \\
(2003)\end{array}$ \\
\hline Vír & $9 \times 6 \mathrm{~km}$ & $\begin{array}{c}\text { junction of } \\
\text { Svratka and } \\
\text { Polička units }\end{array}$ & $1.6 \mathrm{GPa}, 860-1000{ }^{\circ} \mathrm{C}$ & $0.6-0.8 \mathrm{GPa}, 600^{\circ} \mathrm{C}$ & $\begin{array}{c}\mathrm{U}-\mathrm{Pb} \text { zircon } 354 \pm 7 \mathrm{Ma} \text {, } \\
\text { monazite in orthogneiss } \\
338 \pm 3 \mathrm{Ma}^{* * *}\end{array}$ & $\begin{array}{l}\text { van Breemen et al. } \\
\text { (1982), Štoudová } \\
\text { et al. (1999), } \\
\text { Tajčmanová et al. } \\
(2010)\end{array}$ \\
\hline
\end{tabular}

* $\mathrm{U}-\mathrm{Pb}$ age determinations on zircon are interpreted as dating the HP events

** unpublished data R. Nahodilová

*** van Breemen et al. (1982) attributed this monazite age to low-T shearing and fluid activity

2009). In Běstvina, the composition of the outer zone of garnet in granulites, perfect preservation of kyanite, and the absence of newly formed LP phases all indicate a mild decompression $(\mathrm{P} \sim 1.4 \mathrm{GPa})$ in the kyanite field. The major contrast in the $\mathrm{P}-\mathrm{T}$ path of the two types of granulites (Fig. 2a) excludes any joint evolution as parts of a former coherent unit with the Moldanubian Zone. In addition, the Běstvina granulite in Kutná Hora Unit has age of HP metamorphism by 20 Ma older than Moldanubian granulites (Tab. 3). The third mode of granulite occurrence (Vír) represents a segment directly at the junction of the Svratka and Polička units. These rocks preserve an evidence for decompression recrystallization similar to that in granulites of the Moldanubian Zone (Štoudová et al. 1999; Tajčmanová et al. 2010), but the original source of these thrust-slices remains uncertain.

\subsubsection{Skarns}

The geochemical features of the studied skarns do not indicate systematic differences among the three studied geological units, although their tectono-metamorphic development was different. The $\delta^{18} \mathrm{O}$ (SMOW) values for garnet and clinopyroxene from skarn localities in the Moldanubian Zone and the Svratka Unit are low, ranging from -0.1 up to +4.0 (Pertold et al. 1997; Pertoldová et al. 1998, 2009; Drahota et al. 2005). Such low values do not support the idea of contact metamorphic genesis (Pertoldová et al. 2009).

Based on the major- and trace-element geochemistry and the geological position, the skarn protoliths are instead interpreted as rocks of mixed detrital-exhalative origin deposited on a sea floor. The total REE contents and type of Eu anomaly are highly variable and indicate variations in the local temperature and redox conditions among the individual layers at a single locality, as well as various localities (Pertoldová et al. 2009). There is also an indication of a rather conservative character of the metamorphism with limited migration of components within the garnet-clinopyroxene rocks. It is probable that hydrothermal solutions, instrumental in the development of skarn protoliths, debouched on the sea floor along fault zones with the character of local extensional rifts. The deposition of exhalites proceeded along such zones, and they were mixed with detrital material in variable proportions. The large variability of the zircon ages in skarn from the Svratka Unit suggests their detrital origin. The fact that most of the data falls between 540 and $580 \mathrm{Ma}$ possibly indicates a source in the rocks of Neoproterozoic age (Pertoldová et al. 2009).

\subsection{Geodynamic evolution}

\subsubsection{Indicators of Pre-Variscan tectonometamorphic evolution}

Field relationships between different rock-types, presence of relict structures, geochronology and $\mathrm{P}-\mathrm{T}$ data originating from the Svratka Unit provide an evidence for important role of pre-Variscan geodynamic events. Discordant intrusive contacts between Cambrian granites dated by Schulmann et al. (2005) at $515 \pm 9 \mathrm{Ma}$ and the surrounding migmatites, as well as the absence of additional Variscan partial melting and high-grade overprint, 
indicate that the previously identified HP-HT event in skarns (Buriánek et al. 2009b; Pertoldová et al. 2009; Verner et al. 2009) must have been of pre-Variscan age. On a regional scale, the HP-HT processes including extensive partial melting and emplacement of calc-alkaline granitoids could be related with crustal exhumation in final stages of the Cadomian orogenic processes, or with continental extension during early Cambrian rifting (Linnemann et al. 2000). In contrast to the published models (e. g. Pitra et al. 1994; Mazur et al. 2005; Schulmann et al. 2005, 2008), the Svratka Unit was affected by Variscan regional metamorphism reaching amphibolitefacies conditions only (Fig. 2b; P-T path 5). This is in sharp contrast to the high-grade Kutná Hora Unit and the Moldanubian Zone.

\subsubsection{High-grade metamorphic events of the Variscan age}

Granulites as a typical and ubiquitous rock-type are excellent objects for comparison of tectonometamorphic and geochronological evolution in the high-grade Strážek Unit, Kutná Hora Unit and Vír area. Granulites of the Strážek Unit recorded a rapid, nearly isothermal MP-LP decompression recrystallization at $\sim 340 \mathrm{Ma}$ (Tajčmanová et al. 2006; Verner et al. 2009). In contrast, granulites of the Kutná Hora Unit are characterized by a perfect preservation of kyanite and an absence of newly formed low-pressure mineral assemblages (Synek and Oliveriová 1993; Vrána et al. 2005, 2009) (Tab. 3). The Vír granulite body occurs in a tectonic position between the less metamorphosed Svratka and Polička units; however the estimated $\mathrm{P}-\mathrm{T}$ path is similar to other Moldanubian granulites (Tajčmanová et al. 2010). In view of the geochronological data of the HP or UHP rocks in the Kutná Hora Unit (the HP crystallization of Běstvina granulite was dated at 360.4 $\pm 5.3 \mathrm{Ma}$; U-Pb zircon, R. Nahodilová, personal comm.) and in the Orlice-Sněžník Unit (the UHP/HP metamorphic event is constrained to the age range of 360-369 Ma, Klemd and Bröcker 1999; Mazur et al. 2005 and references therein). We suggest that Kutná Hora Unit can be considered as part of the Palaeo-Variscan frame against which rocks of the Moldanubian Zone were exhumed during the Neo-Variscan event (at around $340 \mathrm{Ma}$; Tajčmanová et al. 2006). This interpretation is an alternative to the earlier accepted opinion of Synek and Oliveriová (1993), who considered the Moldanubian Zone to be a passive paraautochthon unit, upon which the allochthonous partial units of the Kutná Hora Unit were overthrust.

Although some geologists refer to the Kutná Hora Unit as belonging to the Gföhl Unit (e.g., Franke 2000; Medaris et al. 2005, 2006, 2009; Faryad 2009; Faryad et al. 2010), it is suggested that use of the latter term should be limited to the Moldanubian Zone.
Importantly, the mineral assemblages and mineral chemistry in metasedimentary gneisses and migmatites hosting granulite massifs correspond to metamorphic pressures significantly lower than those of the Variscan granulites. This indicates that individual granulite bodies may mark former major discontinuities, along which granulites were emplaced as allochthonous segments from deeper structures. The role of granulites as tectonic markers is somewhat similar to that of metabasic eclogites and peridotites/lherzolites.

\subsubsection{Structural evolution}

The structural information for the Palaeo-Variscan (390-355 Ma) HP and UHP events identified on the basis of geochronological data in the Kutná Hora and OrliceSněžník Units (R. Nahodilová, unpublished data; Mazur et al. 2005) remains unknown.

In the Moldanubian Zone, only a few geochronological data indicate Palaeo-Variscan processes in garnet-pyroxenites and eclogites (Carswell and Jamtveit 1990; Beard et al. 1992), no information is available from metasedimentary complexes.

The first well-recorded event of the Variscan geodynamic evolution in the northern part of the studied area (Svratka, Polička and Zábřeh units) were widely distributed WNW-ESE right-lateral, transpressional to transtensional deformations. This event proceeded under $\mathrm{T}=\sim 580-650$ ${ }^{\circ} \mathrm{C}$ and $\mathrm{P}=\sim 0.5-0.7 \mathrm{GPa}$, in the Polička and Zábřeh units dated by synchronous emplacement of calc-alkaline granitoids at around 352-343 Ma (Vondrovic and Verner 2008, unpublished data; Verner et al. 2009). On a regional scale, a similar kinematic framework was documented along the Teplá-Barrandian/Moldanubian boundary, in this case dated by syntectonic emplacement of the slightly older calc-alkaline Sázava and the high-K calc-alkaline Blatná plutonic suites of the Central Bohemian Plutonic Complex (Janoušek et al. 2004, 2010b; Žák et al. 2005, 2009). In the high-grade Strážek Unit (northeastern part of the Moldanubian Zone), a set of several younger metamorphic fabrics was formed. These reflect partial stages of a very fast exhumation of deep-seated rocks at around $340 \mathrm{Ma}$ : (1) development of relict HP structures in felsic granulites, which correspond to early stages of their lower-crustal evolution dated at $340 \pm 1.1 \mathrm{Ma}$ (Schulmann et al. 2005; Tajčmanová et al. 2006); (2) regional, medium-pressure, steeply dipping NNE-SSW foliations reflecting an episode of exhumation (Schulmann et al. 2008); (3) formation of flat-lying fabrics during a sub-vertical shortening of partly exhumed rocks (Verner et al. 2008) and (4) structures of thrusting of Moldanubian rocks over the less metamorphosed or unmetamorphosed rocks of the Moravo-Silesian Zone during lateral indentation of the Brunia continent (Schulmann et al. 2008). In contrast to results of previously 
published papers (Tajčmannová et al. 2006; Schulmann et al. 2005, 2008), the upper limit for all these events in the NE part of the Moldanubian Zone is age-constrained by the post-tectonic mid- to upper-crustal emplacement of the durbachites (Dosbaba and Sulovský 2006; Verner et al. 2009). Durbachite bodies intruded in the eastern part of the Moldanubian Zone were dated by several authors in the range 341-323 Ma (Schulmann et al. 2005; Verner et al 2009; Janoušek et al. 2010a; Kotková et al. 2010; Kusiak et al. 2010). However, reliable geochronological data sets from porphyritic Moldanubian durbachites give a clear evidence of emplacement and crystallization of these rocks close to $339 \mathrm{Ma}$ (Verner et al 2008; Janoušek et al. 2010a; Kusiak et al. 2010). On a regional scale, the flat-lying and thrusting fabrics (points 3 and 4 described above) were in the southern part of the overlying Svratka Unit superimposed on older transpressional to transtensional fabrics defined in the Svratka, Polička and Zábřeh units. The initial phase of the extensional tectonics in this part of the Bohemian Massif began somewhat later than $\sim 338-333 \mathrm{Ma}$, with formation of the NNE-SSW system of HT to LT mylonitized zones (e. g. Přibyslav mylonite Zone; Verner et al. 2006). A good example of the presence of this extensional event is partial low-temperature reworking of the NNE-SSW trending shear zone which separates the less metamorphosed Hlinsko Unit from the Polička and Svratka units (Pitra et al. 1994; Vondrovic and Verner unpublished data). In case of the Orlice-Sněžník Unit (Western Sudetes) a distinct set of various regional fabrics reflecting partial stages of orogenic exhumation by $c$. $\sim 345 \mathrm{Ma}$ was described (Mazur et al. 2005). However, these exhumation structures have a different character and orientation compared to the presently studied units. Structural relationships between the southern part of the Orlice-Sněžník Unit and the overlying Zábřeh Unit are unclear. The reason could be the spatial occurrence of conspicuous system of right-lateral WNW-ESE fault structures of the "Elbe Zone", the activity of which is constrained by syntectonic emplacement of the Meissen Massif at $334 \mathrm{Ma}$ and and the intrusion of the Markersbach granite dated at $327 \mathrm{Ma}$ (Hofmann et al. 2008); Linnemann et al. (2008) suggested that the activity started already at around $343 \mathrm{Ma}$.

Acknowledgements. This research was supported by Project No. 6352 of the Czech Geological Survey and the Ministry of Environment, Internal Research Project No. 3270 of the Czech Geological Survey and the Grant Agency of Charles University No. 81909. We thank Zdeněk Pertold for his helpful discussions and constructive comments. Madeleine Štulíková is thanked for revising the English of this manuscript. We appreciate the help of the reviewers Pavel Hanžl and Gernold Zulauf, which contributed to improving the manuscript. We also thank Vojtěch Janoušek for his careful editorial work.
Electronic supplementary material. The GPS coordinates of the analysed samples, as well as whole-rock geochemical data from metasediments of the Hlinsko, Polička and Zábřreh units (Appendix 1) and Svratka and Strážek units (Appendix 2) are available online at the Journal web site (http://dx.doi.org/10.3190/jgeosci.083).

\section{References}

Ackerman L, Jelínek E, Medaris G, Ježek J, Siebel W, STRNAD L (2009) Geochemistry of Fe-rich peridotites and associated pyroxenites from Horní Bory, Bohemian Massif; insights into subduction-related melt-rock reactions. Chem Geol 259: 152-167

Anczkiewicz R, Szczepański J, Mazur S, Storey C, Crowley Q, Villa IM, Thirlwall M (2007) Lu-Hf geochronology and trace element distribution in garnet: implications for uplift and exhumation of ultra-high pressure granulites in the Sudetes, SW Poland. Lithos 95: 363-380

BEA F (1996) Residence of REE, Y, Th and U in granites and crustal protoliths; implications for the chemistry of crustal melts. J Petrol 37: 521-552

Beard BL, Medaris LG Jr., Johnson CM, Brueckner HK, MísAř Z (1992) Petrogenesis of Variscan high-temperature group A eclogites from the Moldanubian Zone of the Bohemian Massif, Czechoslovakia. Contrib Mineral Petrol 111: 468-483

Breiter K, Čopjaková R, Gabašová A, Š́Koda R (2005) Chemistry and mineralogy of orthogneisses at the northeastern part of the Moldanubicum. J Czech Geol Soc 50: 81-94

Buriánek D (2009) Petrography of the Polička Crystalline Complex. Acta Mus Moraviae, Sci Nat 94: 3-46

BuriáNEK D (2010) Comparison of metasediments from Hlinsko Zone, Polička and Zábřreh crystalline complexes based on the whole rocks chemical composition. Geol výzk na Moravě a Slezsku 17: 35-39 (in Czech)

Buriánek D, Otava J (2007) Three genetically different types of garnet-rich rocks from Hlinsko Zone and from Polička Crystaline Complex. Acta Mus Moraviae, Sci Nat 92: 143-150 (in Czech)

BuriáNeK D, ČopJaková R (2009) Metamorphic evolution of mica schists and their tectonic position in the Polička Unit. Acta Mus Moraviae, Sci Nat 94: 111-128 (in Czech)

Buriánek D, NĚMečKovÁ M, HanžL P (2003) Petrology and geochemistry of plutonic rocks from the Polička and Zábřeh crystalline units (NE Bohemian Massif). Bull Czech Geol Surv 78: 9-22

Buriánek D, Hrdličková K, Hanžl P (2009a) Geological position and origin of augen gneisses from the Polička Unit, eastern Bohemian Massif. J Geosci 54: 201-219

Buriánek D, Verner K, Hanžl P, Krumlová H (2009b) Petrochemical and microstructural comparison between 
Cambro-Ordovician metagranites and migmatites of the Svratka Unit and the Orlice-Sněžník Unit. J Geosci 54: 181-200

BuriánKová K, BŘízová E, Fürych V, HanžL P, KadLECová R, Kirchner K, Lysenko V, Lhotský P, Mrnková J, Pertoldová J, Roštínský P, Skácelová D, Trávníček B, Vít J (2008) Basic geological map ČR 1:25 000 with explanation 23-224 Žd'ár nad Sázavou. Czech Geological Survey, Prague, pp 1-78 (in Czech)

Carswell DA, Jamtveit (1990) Variscan Sm-Nd ages for the high-pressure metamorphism in the Moldanubian Zone of the Bohemian Massif, Lower Austria. Neu Jb Mineral, Abh 162: 69-78

Cháb J, Breiter K, Fatka O, Hladil J, Kalvoda J, Šimưnek Z, Štorch P, VAŠíčeK Z, Zajíc J, ZAPLetal J (2010) Outline of the Geology of the Bohemian Massif: the Basement Rocks and their Carboniferous and Permian Cover. Czech Geological Survey, Prague, pp 1-296

Chaloupský J, Chlupáč I, Mašek J, Waldhausrová J, Cháb J (1995) Teplá-Barrandian Zone (Bohemicum) - Stratigraphy. In: Dallmeyer RD, Franke W, Weber K (eds) Pre-Permian Geology of Central and Eastern Europe. Springer-Verlag, Berlin, 379-391

Chlupéč I, Štorch P (eds) (1992) Regional division of the Bohemian Massif in Czech Republic. Report of Commitee for Regional Geologic Classification. Čas Mineral Geol 37: 257-275 (in Czech)

Dosbaba M, Sulovský P (2006) Geology, petrology and geochemistry of durbachite bodies around Nové Město na Moravě. Acta Mus Moraviae, Sci Nat 91: 177-190 (in Czech)

Dostal J, Chatterjee AK (2000) Contrasting behaviour of $\mathrm{Nb} / \mathrm{Ta}$ and $\mathrm{Zr} / \mathrm{Hf}$ ratios in peraluminos granitic pluton (Nova Scotia, Canada). Chem Geol 163: 207-218

Drahota P, Pertold Z, Pudilová M (2005) Three types of skarn in the northern part of the Moldanubian zone, Bohemian Massif - implications for their origin. J Czech Geol Soc 50: 19-33

Drost K, Linnemann U, McNaughton N, Fatka O, Kraft P, Gehmlich M, Tonk Ch, MareK J (2004) New data on the Neoproterozoic-Cambrian geotectonic setting of the Teplá-Barrandian volcano-sedimentary successions: geochemistry, $\mathrm{U}-\mathrm{Pb}$ zircon ages, and provenance (Bohemian Massif, Czech Republic). Int J Earth Sci 93:742-757

FAJST M (1976) A new unconformity in the Precambrian of the Bohemian Massif. Cas Mineral Geol 21: 257-275 (in Czech)

FARYAD SW (2009) The Kutná Hora Complex (Moldanubian Zone, Bohemian Massif): a composite of crustal and mantle rocks subducted to HP/UHP conditions. Lithos 109: 193-208

Faryad SW, Nahodilová R, Dolejš D (2010) Incipient eclogite facies metamorphism in the Moldanubian granulites revealed by mineral inclusions in garnet. Lithos 114: 54-69

Fiala J, Fuchs G, Wendt JI (1995) Moldanubian Zone - Stratigraphy. In: Dallmeyer RD, Franke W, Weber K (eds) Pre-Permian Geology of Central and Eastern Europe. Springer, Berlin, pp 417-428

Finger F, Gerdes A, Janoušek V, René M, Riegler G (2007) Resolving the Variscan evolution of the Moldanubian sector of the Bohemian Massif: the significance of the Bavarian and the Moravo-Moldanubian tectonometamorphic phases. J Geosci 52: 9-28

Franke W (2000) The mid-European segment of the Variscides: tectonostratigraphic units, terrane boundaries and plate tectonic evolution. In Franke W, HAAK W, ONCKEN O, TANner D (eds) Orogenic Processes: Quantification and Modelling in the Variscan Belt. Geological Society of London Special Publications 179: 35-63

Fritz H, Dallmeyer R D, Neubauer F (1996) Thick-skinned versus thin-skinned thrusting: rheology controlled thrust propagation in the Variscan collisional belt (the southeastern Bohemian Massif, Czech Republic-Austria). Tectonics 15: 1389-1413

HanžL P, BuriánKová K, Kabátník P, Finger F (2000) Results of geological mapping of the NE part of the Zábřeh Crystalline Unit. Geol výzk Mor Slez v r 1999 7: 116-119 (in Czech)

HanžL P, Buriánková K, Bešta J, BlažKová Š, BŘízová E, Dosbaba M, Fürych V, Kirchner K, Kryštofová E, Lysenko V, Pertoldová J, Roštínský P, RÝda K, SKÁcelová D, Skácelová Z, Vít J, ZavŘelová A, Ž́áčKová E (2008a) Basic geological map ČR 1:25 000 with explanation, 24-113 Nové Město na Moravě. Czech Geological Survey, Prague, pp 1-79 (in Czech)

Hanžl P, Buriánek D, Čurda J, Fürich V, HrdlčKová K, Kirchner K, Lysenko V, Mrnková J, Otava J, Pertoldová J, RoštínskÝ P, RÝda K, SKÁcelová Z, Vít J, ZelenKa P (2008b) Basic geological map ČR 1:25 000 with explanation, 14-333 Svratka. Czech Geological Survey, Prague, pp 1-72 (in Czech)

Hegner E, KRÖNER A (2000) Review of Nd isotopic data and xenocryst and detrital zircon ages from the pre-Variscan basement in the eastern Bohemian Massif: speculations on palinspatic reconstructions. In Franke W, HaAK W, OnCKen O, TANner D (eds) Orogenic Processes: Quantification and Modelling in the Variscan Belt. Geological Society London Special Publications 179: 113-129

Hofmann M, Linnemann U, Gerdes A, Ullrich B (2008) Closure of the Rheic Ocean and the final pulse of the Variscan Orogeny in the Bohemian Massif - timing of large-scale strike-slip processes and basement exhumation by LA-ICP-MS U-Pb zircon dating from the Elbe Zone (Saxo-Thuringian Zone, Germany). Final Meeting of IGCP 497 and IGCP 499, Abstract and Programme, Frankfurt am Main, pp 53 
Holdaway MJ (1971) Stability of andalusite and the aluminium silicate phase diagram. Amer J Sci 271: 97-131

INGER S, HARRIS N (1993) Geochemical constraints on leucogranite magmatism in the Langtang Valley, Nepal Himalaya. J Petrol 34: 345-368

Janoušek V, Braithwaite CJR, Bowes DR, Gerdes A (2004) Magma-mixing in the genesis of Hercynian calc-alkaline granitoids: an integrated petrographic and geochemical study of the Sázava intrusion, Central Bohemian Pluton, Czech Republic. Lithos 78: 67-99

Janoušek V, Gerdes A, Holub FV, Verner K (2010a) Dating Variscan ultrapotassic intrusions in the Bohemian Massif - separating myth from reality. In: Конúт M (ed.) Datovanie 2010, Zborník abstraktov. Štátny geologický ústav Dionýza Štúra, Bratislava, 15-16

JANOUŠEK V, WiEGAND B, Ž́́K J (2010b) Dating the onset of Variscan crustal exhumation in the core of the Bohemian Massif: new U-Pb single zircon ages from the high-K calc-alkaline granodiorites of the Blatná suite, Central Bohemian Plutonic Complex. J Geol Soc, London 167: 347-360

JASTRZĘBSKI M (2009) A Variscan continental collision of the West Sudetes and the Brunovistulian terrane: a contribution from structural and metamorphic records of the Stronie Formation, the Orlica-Śniežnik Dome, SW Poland. Int J Earth Sci 98: 1901-1923

KACHLíK V (1999) Relationship between Moldanubicum, the Kutná Hora Crystalline Unit and Bohemicum (Central Bohemia, Czech Republic): a result of polyphase Variscan nappe tectonics. J Czech Geol Soc 44: 201-291

KLEMD R, BRÖCKER M (1999) Fluid influence on mineral reactions in ultrahigh-pressure granulites: a case study in the Śnieżnik Mts. (West Sudetes, Poland): Contrib Mineral Petrol 136: 358-373

Kotková J, Melichar R, Pokorná J (2003) The story of Bory granulites - early thoughts. Geolines 16: 57

Kotková J, Schaltegger U, Leichmann J (2010) Two types of ultrapotassic plutonic rocks in the Bohemian Massif - coeval intrusions at different crustal levels: Lithos 115: $163-176$

Koutek J (1933) Geology of the crystalline area along the Sázava River. Věst Stát Geol úst 9: 319-353 (in Czech)

Kröner A, Wendt I, Liew TC, Compston W, Todt W, Fiala J, VAŇKOVÁ V, VANĚK J (1988) U-Pb zircon and Sm-Nd model ages of high-grade Moldanubian metasediments, Bohemian Massif, Czechoslovakia. Contrib Mineral Petrol 99: 257-266

Kröner A, ŠTíPskÁ P, Schulmann K, JAeckel P (2000) Chronological constraints on the pre-Variscan evolution of the northeastern margin of the Bohemian Massif, Czech Republic. In Franke W, HaAk W, OnCKen O, TANner D (eds) Orogenic Processes: Quantification and Modelling in the Variscan Belt. Geological Society London Special Publications 179: 175-198
Kröner A, Jaeckel P, Hegner E, Opletal M (2001) Single zircon ages and whole rock $\mathrm{Nd}$ isotopic systematics of early Palaeozoic granitoid gneisses from the Czech and Polish Sudetes (Jizerské hory, Krkonoše Mountains and Orlice-Sněžník Complex). Int J Earth Sci 90: 304-324

Kryza R, Pin C, Vielzeuf D (1996) High-pressure granulites from the Sudetes (south-west Poland); evidence of crustal subduction and collisional thickening in the Variscan Belt. J Metamorph Geol 14: 531-546

Kusiak MA, Dunkley DJ, Suzuki K, Kachlík V, Kedzior A, LeKKi J, Opluštil S (2010) Chemical (non-isotopic) and isotopic dating of Phanerozoic zircon - a case study of durbachite from the Třebíč Pluton, Bohemian Massif. Gondwana Res 17: 153-161

Lewis JS (2004) Physics and Chemistry of the Solar System. $2^{\text {nd }}$ ed, Elsevier, Amsterdam, pp 1-655

Linnemann U, Gehmlich M, Tichomirowa M, Buschmann B, Nasdala L, Jonas P, Lützner H, Bombach K (2000) From Cadomian subduction to Early Paleozoic rifting: the evolution of Saxo-Thuringia at the margin of Gondwana in the light of single zircon geochronology and basin development (central European Variscides, Germany). In Franke W, HaAK W, Oncken O, TANner D (eds) Orogenic Processes: Quantification and Modelling in the Variscan Belt. Geological Society of London Special Publications 179: 131-153

Linnemann U, Pereira F, Jeffries T E, Drost K, Gerdes A (2008) The Cadomian Orogeny and the opening of the Rheic Ocean: the diacrony of geotectonic processes constrained by LA-ICP-MS U-Pb zircon dating (OssaMorena and Saxo-Thuringian zones, Iberian and Bohemian massifs). Tectonophysics 461: 21-43

LinNen RL, KePPLeR H (2002) Melt composition control of $\mathrm{Zr} / \mathrm{Hf}$ fractionation in magmatic processes. Geochim Cosmochim Acta 66: 3293-3301

LOSERT J (1967) Contribution to the problem of the pre-Assyntian tectogenesis and metamorphism in the Moldanubicum of the Bohemian Massif. Krystalinikum 5: 61-84

Maynard JB (2005) Manganiferous Sediments, Rocks and Ores. In: MackenzIE FT (ed) Sediments, Diagenesis and Sedimentary Rocks. Treatise on Geochemistry, volume 7. Elsevier, Amsterdam, 289-308

MacheK M, Ulrich S, JANOUŠEK V (2009) Strain coupling between upper mantle and lower crust: natural example from the Běstvina granulite body, Bohemian Massif. J Metamorph Geol 27: 721-737

Mazur S, Aleksandrowski P, Szczepański J (2005) The presumed Teplá-Barrandian/Moldanubian terrane boundary in the Orlica Mountains (Sudetes, Bohemian Massif): structural and petrological characteristics. Lithos 82 : 85-112

Mazur S, Kröner A, Szczepański J, Turniak K, Hanžl P, Melichar R, Rodionov NV, Paderin I, Sergeev SA 
(2010) Single zircon U-Pb ages and geochemistry of granitoid gneisses from SW Poland: evidence for an Avalonian affinity of the Brunian microcontinent. Geol Mag 147: 508-526

McLennan SM, Taylor SR, McCulloch MT, Maynard JB (1990) Geochemical and Nd-Sr isotopic composition of deep-sea turbidites: crustal evolution and plate tectonic associations. Geochim Cosmochim Acta 54: 2015-2050

McLennan SM, Hemming S, McDaniel DK, Hanson GN (1993) Geochemical approaches to sedimentation, provenance and tectonics. In: JoHnsson MJ, Basu A (eds) Processes Controlling the Composition of Clastic Sediments. Geological Society of America Special Papers 284: $21-40$

Medaris G Jr, Beard BL, Johnson CM, Valley JW, Spicuzza MJ, JeLínek E, Mísař Z (1995) Garnet pyroxenite and eclogite in the Bohemian Massif: geochemical evidence for Variscan recycling of subducted lithosphere. Geol Rundsch 84: 489-505

Medaris G Jr, Fournelle JH, Ghent ED, Jelínek E, Mísař Z (1998) Prograde eclogite in the Gföhl Nappe, Czech Republic: new evidence on Variscan high-pressure metamorphism. J Metamorph Geol 16: 563-576

Medaris G Jr, Wang H, Jelínek E, Mihaljevič M, Jakeš P (2005) Characteristics and origins of diverse Variscan peridotites in the Gföhl Nappe, Bohemian Massif, Czech Republic. Lithos 82: 1-23

Medaris G Jr, Ghent ED, Wang HF, Fournelle JH, Jelínek E (2006) The Spačice eclogite: constrains on the P-T-t history of the Gföhl granulite terrane, Moldanubian Zone, Bohemian Massif. Mineral Petrol 86: 203-220

Medaris G Jr, Ackerman L, Jelínek E, Toy V, Siebel W, ТікоғF B (2009) The Sklené garnet peridotite; petrology, geochemistry, and structure of a mantle-derived boudin in Moldanubian granulite. J Geosci 54: 301-323

Melichar R (1995) The structural analysis of the Polička and Svratka units. Unpublished $\mathrm{PhD}$ thesis, Charles University, Prague, pp 1-271 (in Czech)

Melichar R, BŘizová E, Buriánek D, Čurda J, Fürych V, Hanžl P, HrdličKová K, Kirchner K, LysenKo V, MrnKová J, RoštínskÝ P, RÝdA K, SKÁcelová Z, Vít J (2008) Basic geological map ČR 1:25 000 with explanation, 24-111 Sněžné. Czech Geological Survey, Prague, pp 1-58 (in Czech)

Mísař Z, Dudek A, Havlena V, Weiss J (1983) Geology of the Bohemian Massif. SPN, Prague, pp 1-334 (in Czech)

Naemura K, Hisashima H, Hirajima T, Svojtka M (2009) An ultra-high-pressure metamorphic condition and isothermal decompression path obtained from a garnetpyroxenite in the Horní Bory granulite of the Bohemian Massif. J Mineral Petrol Sci 104: 168-175

Nahodilová R, Faryad S, Pertoldová J, Konopásek J, ŠTĚDRÁ V (2006) Contrasting metamorphic evolution of HP rocks in the Gföhl Unit of the Kutná Hora Crystal- line Complex and the Moldanubian Zone in Austria. Geolines 20: 98-99

NovÁK JK, VRBOVÁ H (1994) Petrogenesis and geochemistry of mafic rocks from the Kutná Hora Crystalline Complex and the neighbouring part of the Rataje Micaschist Zone. Geolines 4: 1-41

Oliveriová D, Synek J, Maluski H (1995) Dating middle and late Variscan tectonometamorphic events on the NE rim of the Moldanubian Zone, Kutná Hora Crystalline Complex; an ${ }^{39} \mathrm{Ar} /{ }^{40} \mathrm{Ar}$ study. J Czech Geol Soc 40: 35

Opletal M, DomečKa K, Čech S (1980) Geology of the Orlické hory Mts. Academia, Prague, pp 1-202 (in Czech with extended English summary)

Owen JV, Dostal J (1996) Prograde metamorphism and decompression of the Gföhl Gneiss, Czech Republic. Lithos 38: 259-270

PADĚRA K (1972) Griquaites in the Moldanubicum of the Bohemian Massif. In: ZoubeK V (ed) Upper Mantle Project Programme in Czechoslovakia 1962-1970. Geology - Final Report. Academia Praha, 51-59

Patočka F, Pruner P, Štorch P (2003) Palaeomagnetism and geochemistry of Early Palaeozoic rocks of the Barrandian (Teplá-Barrandian Unit, Bohemian Massif): palaeotectonic implications. Phys Chem Earth 28: 735-749

Pertold Z, Pertoldová J, Potužák M, Pudilová M, Bendl J, Janoušek V, Zachariáš J, Siriro B, Greenwood PB (1997) Skarns of the Bohemian Massif: origin in closed or open systems? J Czech Geol Soc 42: 69

Pertoldová J, Pertold Z, Pudilová M (1998) Metamorphic development of skarns at Pernštejn, Svratka Crystalline Complex, Bohemian Massif. J Czech Geol Soc 43: 191-202

Pertoldová J, Buriánek D, Hrdličková K, Čapek D, Čopjaková R, Schulmannová B, Dušek K, Haloda J, Hanžl P, Konopásek J, KopačKová V, Košuličová M, Malec J, Nahodilová R, Soejono I, Sulovský P, ŠKoda R, ŠTĚdRÁ V, TÁborskÝ Z, TaJČmanová L, TÝcová P, Verner K, Veselovský F, Vondrovic L, Vrána S, ZavŘelová A, Ž́áčová E, Šrámek J, Melichar R (2007) Investigation of litologically contrasting rocks in the crystalline units at the NE margin of the Moldanubian Zone - continuation of basic geological mapping 1:25000. Unpublished manuscript, Archive of the Czech Geological Survey, Prague, pp 1-333 (in Czech)

Pertoldová J, Týcová P, Verner K, Košuličová M, Pertold Z, KošLer J, Konopásek J, Pudilová M (2009) Tectonometamorphic history of skarns, origin and age of their protolith and implications for genetic interpretation; an example from the Svratka Unit, the Moldanubian Zone, and the Kutná Hora Unit, Bohemian Massif. J Geosci 54: 101-134

Pitra P, Guiraud M (1996) Probable anticlockwise P-T evolution in extending crust: Hlinsko region, Bohemian Massif. J Metamorph Geol 14: 49-60 
Pitra P, Burg J P, Schulmann K, Ledru P (1994) Late-orogenic extension in the Bohemian Massif: petrostructural evidence in the Hlinsko region. Geodin Acta 6: 15-31

Quin L, Humayun M (2008) The Fe/Mn ratio in MORB and OIB determined by ICP-MS. Geochim Cosmochim Acta 72: 1660-1677

Roser BP, Nathan S (1997) An evaluation of elemental mobility during metamorphism of a turbidite sequence (Greenland Group, New Zealand). Geol Mag 134: 219-234

Schulmann K, Gayer R (2000) A model for a continental accretionary wedge developed by oblique collision: the NE Bohemian Massif. J Geol Soc, London 157: 401-416

Schulmann K, Kröner A, Hegner E, Wendt I, KonopáseK J, LEXA O, ŠTíPSKÁ P (2005) Chronological constraints on the pre-orogenic history, burial and exhumation of deepseated rocks along the eastern margin of the Variscan Orogen, Bohemian Massif, Czech Republic. Amer J Sci 305: 407-448

Schulmann K, Lexa O, Štípská P, Racek M, Tajčmanová L, Konopásek J, Edel JB, Peschler A, Lehmann J (2008) Vertical extrusion and horizontal channel flow of orogenic lower crust: key exhumation mechanisms in large hot orogens? J Metamorph Geol 26: 273-297

Schulmann K, KonopáseK J, Janoušek V, Lexa O, Lardeaux JM, Edel JB, ŠTíPSKÁ P, Ulrich S (2009) An Andean type Palaeozoic convergence in the Bohemian Massif. C R Geosci 341: 266-286

STAŇKOVÁ J (1982) "Dist-sillimanite": its importance for assessment of polyphase metamorphism in the leptynite body near Bory, Czechoslovakia. Krystalinikum 16: 53-66

Synek J, Oliveriová D (1993) Terrane character of the north-east margin of the Moldanubian Zone: the Kutná Hora Crystalline Complex, Bohemian Massif. Geol Rundsch 82: 566-582

ŠTĚDRÁ V, NAHODILOVÁ R (2009) High-pressure metabasic rocks from the Kutná Hora Crystalline Unit, Czech Republic: structural position, geochemical characteristics and metamorphic record of exotic lithologies along the segmented Moldanubian margin, Bohemian Massif. J Geosci 54: 135-157

ŠTĚdRÁ V, BřízovÁ E, Fürych V, KadleCOVÁ R, KirChNER $\mathrm{K}$, Lysenko V, Rambousek P, Roštínský P, Skácelová D, Skácelová Z, Mrnková J, Valigurský L, Zelenka P (2008) Basic geological map ČR 1:25 000 with explanation, 23-221 Ždírec nad Doubravou. Czech Geological Survey, Prague, pp 1-82 (in Czech)

ŠTíPSKÁ P, Schulmann K, KRÖNER A (2004) Vertical extrusion and middle crustal spreading of omphacite granulite: a model of syn-convergent exhumation (Bohemian Massif, Czech Republic). J Metamorph Geol 22: 179-198

ŠToRCH P, KRAFT (2009) Graptolite assemblages and stratigraphy of the lower Silurian Mrákotín Formation, Hlin- sko Zone, NE interior of the Bohemian Massif (Czech Republic). Bull Geosci 84: 51-74

Štoudová S, Schulmann K, KonopáseK J. (1999) A contrast between metamorphic and structural evolution of the Vír Granulite and surrounding rocks of the Polička Crystalline Unit. Geolines 8: 64

TajČmanová L, KonopáseK J, Schulmann K (2006) Thermal evolution of the orogenic lower crust during exhumation within a thickened Moldanubian root of the Variscan belt of Central Europe. J Metamorph Geol 24: 119-134

TAjČmanová L, Soejono I, Konopásek J, KošLer J, Klötzli U (2010) Structural position of high-pressure felsic to intermediate granulites from NE Moldanubian Zone (Bohemian Massif). J Geol Soc, London 167: 329-345

URBAN M, SynEK J (1995) Moldanubian Zone - Structure. In: Dallmeyer RD, Franke W, Weber K (eds) Pre-Permian Geology of Central and Eastern Europe. Springer, Berlin, pp 429-443

VACHTL J (1962) Hlinsko lower Palaeozoic and its relationship to neighbouring units. Sbor Ústřed Úst Geol 27: 341-359 (in Czech)

van Breemen O, Aftalion M, Bowes D R, Dudek A, Mísař Z, Povondra P, VRÁnA S (1982) Geochronological studies of the Bohemian Massif, Czechoslovakia, and their significance in the evolution of central Europe. Trans Roy Soc Edinb, Earth Sci 73: 89-108

Verner K, ŽÁK J, Hrouda F, Holub FV (2006) Magma emplacement during exhumation of the lower- to mid-crustal orogenic root; the Jihlava syenitoid pluton, Moldanubian Unit, Bohemian Massif. J Struct Geol 28: 1553-1567

Verner K, ŽÁ́ J, Nahodilová R, Holub FV (2008) Magmatic fabrics and emplacement of the cone-sheet-bearing Knížecí Stolec durbachitic pluton (Moldanubian Unit, Bohemian Massif); implications for mid-crustal reworking of granulitic lower crust in the Central European Variscides. Int J Earth Sci 97:19-33

Verner K, Buriánek D, Vrána S, Vondrovic L, PerTOLDOVÁ J, HANŽL P, NAHODILOVÁ R (2009) Lithological and structural features of geological units along the northern periphery of the Moldanubian Zone: a review of the geology of the northeastern Variscides. J Geosci 54: $87-100$

VONDROVIC L, VERNER K (2008) The record of structural evolution and $\mathrm{U}-\mathrm{Pb}$ zircon dating of the tonalite intrusions (Polička Crystalline Unit, Bohemian Massif). In Poblet J, Medina MG, Pedreira D, Fernández CL (eds) International Meeting of Young Researches in Structural Geology and Tectonics, Programme and Extended abstracts. University of Oviedo, Spain, pp 369-373

VRÁNA S, KRÖNER A (1995) Pb-Pb zircon ages for tourmaline alkali-feldspar orthogneiss from Hluboká nad Vltavou in southern Bohemia. J Czech Geol Soc 40: 127-131

Vrána S, Blümel P, Petrakakis K (1995) Moldanubian Zone - Metamorphic Evolution. In: DALlMEYER RD, 
Franke W, Weber K (eds) Pre-Permian Geology of Central and Eastern Europe. Springer, Berlin, pp 453-466

VRÁNA S, ŠTĚDRÁ V, FišERA M (2005) Petrology and geochemistry of the Běstvina granulite body metamorphosed at eclogite facies conditions, Bohemian Massif. J Czech Geol Soc 50: 95-106

VRÁNA S, ŠTĚDRÁ V, NAHOdILOVÁ R (2009) Geochemistry and petrology of high-pressure albite-K-feldspar kyanite-garnet felsic gneisses and granulites from the Kutná Hora Unit. J Geosci 54: 159-179

WimMenauer W (1984) Das prävariskische Kristallin im Schwarzwald. Fortschr Mineral 62: 69-86

ZulAuF G (1997) Von der Anchizone bis zur Eklogitfazies: angekippte Krustenprofile als Folge der cadomischen und variscichen Orogenese im Teplá-Barradium (Böhmische Masse). Geotekt Forsch 89: 1-302

Ž́́k J, Schulmann K, Hrouda F (2005) Multiple magmatic fabrics in the Sázava Pluton (Bohemian Massif, Czech Republic): a result of superposition of wrench-dominated regional transpression on final emplacement. J Struct Geol 27: 805-822

Žák J, Dragoun F, Verner K, Chlupáčová M, Holub FV, КАснці́к V (2009) Forearc deformation and strain partitioning during growth of a continental magmatic arc: the northwestern margin of the Central Bohemian Plutonic Complex, Bohemian Massif. Tectonophysics 469: 93-111 